\title{
The characterization of Taklamakan dust properties using a multiwavelength Raman polarization lidar in Kashi, China
}

\author{
Qiaoyun $\mathrm{Hu}^{1}$, Haofei Wang ${ }^{2,4,5}$, Philippe Goloub ${ }^{1}$, Zhengqiang $\mathbf{L i}^{2}$, Igor Veselovskii ${ }^{3}$, Thierry Podvin ${ }^{1}$, Kaitao $\mathbf{L i}^{2}$, \\ and Mikhail Korenskiy ${ }^{3}$ \\ ${ }^{1}$ Univ. Lille, CNRS, UMR 8518 - LOA - Laboratoire d'Optique Atmosphérique, 59000 Lille, France \\ ${ }^{2}$ State Environmental Protection Key Laboratory of Satellite Remote Sensing, Aerospace Information Research Institute, \\ Chinese Academy of Sciences, Beijing, 100094, China \\ ${ }^{3}$ Prokhorov General Physics Institute of the Russian Academy of Sciences, Moscow, 119991, Russia \\ ${ }^{4}$ University of Chinese Academy of Sciences, Beijing, 100101, China \\ ${ }^{5}$ Key Laboratory of Radiometric Calibration and Validation for Environmental Satellites, \\ National Satellite Meteorology Center, Beijing, 100081, China
}

Correspondence: Haofei Wang (wanghf@radi.ac.cn)

Received: 18 April 2020 - Discussion started: 25 May 2020

Revised: 29 September 2020 - Accepted: 1 October 2020 - Published: 17 November 2020

\begin{abstract}
The Taklamakan desert is an important dust source for the global atmospheric dust budget and a cause of the dust weather in East Asia. The characterization of Taklamakan dust in the source region is still very limited. To fill this gap, the DAO (dust aerosol observation) was conducted in April 2019 in Kashi, China. The Kashi site is about $150 \mathrm{~km}$ from the western rim of the Taklamakan desert and is strongly impacted by desert dust aerosols, especially in spring time, i.e., April and May. According to sun-sky photometer measurements, the aerosol optical depth (at $500 \mathrm{~nm}$ ) varied in the range of 0.07-4.70, and the Angström exponent (between 440 and $870 \mathrm{~nm}$ ) in the range of $0.0-0.8$ in April 2019. In this study, we provide the first profiling of the $2 \alpha+3 \beta+3 \delta$ parameters of Taklamakan dust based on a multiwavelength Mie-Raman polarization lidar. For Taklamakan dust, the Ångström exponent related to the extinction coefficient (EAE, between 355 and $532 \mathrm{~nm}$ ) is about $0.01 \pm 0.30$, and the lidar ratio is found to be $45 \pm 7 \mathrm{sr}$ $(51 \pm 8-56 \pm 8 \mathrm{sr})$ at $532(355) \mathrm{nm}$. The particle linear depolarization ratios (PLDRs) are about $0.28-0.32 \pm 0.07$ at $355 \mathrm{~nm}, 0.36 \pm 0.05$ at $532 \mathrm{~nm}$ and $0.31 \pm 0.05$ at $1064 \mathrm{~nm}$. Both lidar ratios and depolarization ratios are higher than the typical values of Central Asian dust in the literature. The difference is probably linked to the fact that observations in the DAO campaign were collected close to the dust source; therefore, there is a large fraction of coarse-mode and gi-
\end{abstract}

ant particles (radius $>20 \mu \mathrm{m}$ ) in the Taklamakan dust. Apart from dust, fine particles coming from local anthropogenic emissions and long-range transported aerosols are also nonnegligible aerosol components. The signatures of pollution emerge when dust concentration decreases. The polluted dust (defined by $\mathrm{PLDR}_{532} \leq 0.30$ and $\mathrm{EAE}_{355-532} \geq 0.20$ ) is featured with reduced PLDRs and enhanced EAE $355-532$ compared to Taklamakan dust. The mean PLDRs of polluted dust generally distributed in the range of $0.20-0.30$. Due to the complexity of the nature of the involved pollutants and their mixing state with dust, the lidar ratios exhibit larger variabilities compared to those of dust. The study provides the first reference of novel characteristics of Taklamakan dust measured by Mie-Raman polarization lidar. The data could contribute to complementing the dust model and improving the accuracy of climate modeling.

\section{Introduction}

Airborne dust is the most abundant aerosol species and accounts for nearly $35 \%$ of the total aerosol mass in the atmosphere (Boucher et al., 2013) with an annual flux of 1000$5000 \mathrm{Tg}$ per year (Engelstaedter et al., 2006; Textor et al., 2006; Huneeus et al., 2011). According to the estimation of Ginoux et al. (2012), about $75 \%$ of the atmospheric dust 
originated from natural emissions, and anthropogenic dust emissions accounted for $\sim 25 \%$.

The area spreading from the Sahara desert, the Arabian Peninsula and Central Asia to East Asia is the most significant natural dust source. Based on model simulations, Tanaka and Chiba (2006) estimated that the Saharan desert contributes up to $\sim 62 \%$ of the total dust emissions, and the contribution from the Arabian Peninsula, Central Asia and East Asia is about half of the Saharan emissions. The dust sources in North and South America and Australia altogether account for about $25 \%$ of total emissions. The suspending dust particles can directly influence the planetary radiation budget and indirectly impact the climate by interfering with cloud properties and cloud processes. Dust particles, as well as other ice nucleating particles (INPs), can aide the formation of ice crystals in the heterogeneous ice nucleation regime. Due to their effective ice nucleating capability and abundant concentration, mineral dust particles are considered the most important INP (Kanji et al., 2017). Recent studies found that atmospheric dust is also linked to the activity of tropical cyclones and rainfall (Reed et al., 2019; Thompson et al., 2019).

A comprehensive dataset of dust properties is of significant importance for understanding the effects of dust on the ecosystem and for reducing the uncertainties of climate models. However, this task is very challenging and needs the support of observational data. The properties of dust particles are determined by the texture of soils, the mineralogical composition, vegetation cover and surface properties, which could vary globally from location to location. The modeling of dust horizontal and vertical distributions and the dust cycle, i.e., dust emission, transport and deposition, is crucial to climatic modeling. So far, the vertically resolved information can only be obtained from lidar (light detection and ranging) measurements. A multiwavelength Mie-Raman polarization aerosol lidar can obtain multiple parameters at a vertical level. This capability makes it a useful tool for aerosol study. The profiles of backscatter coefficient, extinction coefficient and depolarization ratio derived from satellite lidar and ground-based lidars have been used as model inputs and have proven useful for improving the accuracy of model simulation and forecasting (Yumimoto et al., 2008; Campbell et al., 2010; Sekiyama et al., 2010; Wang et al., 2013; Zhang et al., 2011, 2012).

In Asia, dust sources distribute over a large area and cover different terrain types. The high-elevation bare lands in Iran, Afghanistan and Tajikistan and the Taklamakan desert in the Tarim Basin, the Loess plateau and the Gobi desert in China are the main dust sources. In addition, excessive land use and human activities have formed new dust sources. There are a good number of publications reporting transported Asian dust observed in the downwind countries in East Asian (Liu et al., 2002; Murayama et al., 2004; Huang et al., 2008; Iwasaka et al., 2008). Long-range transported dust can cross the Pacific Ocean and occasionally reach the Americas (VanCuren and Cahill, 2002; Uno et al., 2009). However, very few field campaigns have been carried out for studying Asian dust. Compared to Saharan dust, the characteristics of Asian dust were not adequately explored. The earliest field campaign characterizing Asian dust dates back to 1989 when an experiment was carried out in Tajikistan for studying desert dust properties and the impact on meteorological conditions. The CADEX (Central Asian Dust EXperiment) project was planned to provide a dataset of optical and microphysical properties of dust from Central Asia. A multiwavelength Mie-Raman polarization lidar was deployed in Dushanbe, Tajikistan. This results in Hofer et al. (2017) and Hofer et al. (2020) provided important dust properties, such as vertically resolved lidar ratios, linear depolarization ratios and mass concentrations. In 2002 and 2009, a elastic polarization lidar system (without Raman channel) was set up in Aksu $\left(40.62^{\circ} \mathrm{N}, 80.83^{\circ} \mathrm{E}\right)$ in Xinjiang, China, near the northern rim of the Taklamakan desert (Kai et al., 2008; Jin et al., 2010). Jin et al. (2010) obtained the first lidar ratio of the Taklamakan dust in the source region; however, it requires extra assumptions and supplementary measurements. Sparse lidar observations downwind of transported Taklamakan dust have been reported, but none of them provides intensive dust characteristics, and the observation sites are far from the desert.

In 2019, the DAO (dust aerosol observation) campaign was conducted from April to June in China. This campaign was supported by the "Belt and Road Initiative" and involved researchers from China, France and Russia. The first observation site in the DAO campaign was in Kashi, China (also called Kashgar), in April 2019, which is about $150 \mathrm{~km}$ from the western rim of the Taklamakan desert. The objective of the first session of the DAO campaign was to study the characteristics of Taklamakan dust. The second session of the campaign was in Beijing in May and June to investigate the impact of transported dust on the air quality in the megacity. The main topic of this paper is the characterization of Taklamakan dust; therefore, only the measurements in Kashi will be analyzed. This study is organized into five sections. The description of the DAO campaign is presented in Sect. 2, and the results and case study are in Sect. 3. The discussions and conclusions are presented in Sects. 4 and 5, respectively.

\section{The dust aerosol observation campaign}

\subsection{Overview}

The Taklamakan desert is located in the center of the Tarim Basin in the Uygur Autonomous Region of Xinjiang, China, covering an area of about $320000 \mathrm{~km}^{2}$. The mean elevation of the Taklamakan desert is about $1200-1500 \mathrm{~m}$ above sea level (Petrov and Alitto, 2019). It is surrounded in three directions by high mountain ranges (see Fig. 1).

The observation site $\left(39.51^{\circ} \mathrm{N}, 75.93^{\circ} \mathrm{E}\right.$; time zone: GMT+08:00) is in the northwest of the city of Kashi and close to the border with Tajikistan, Kyrgyzstan and 


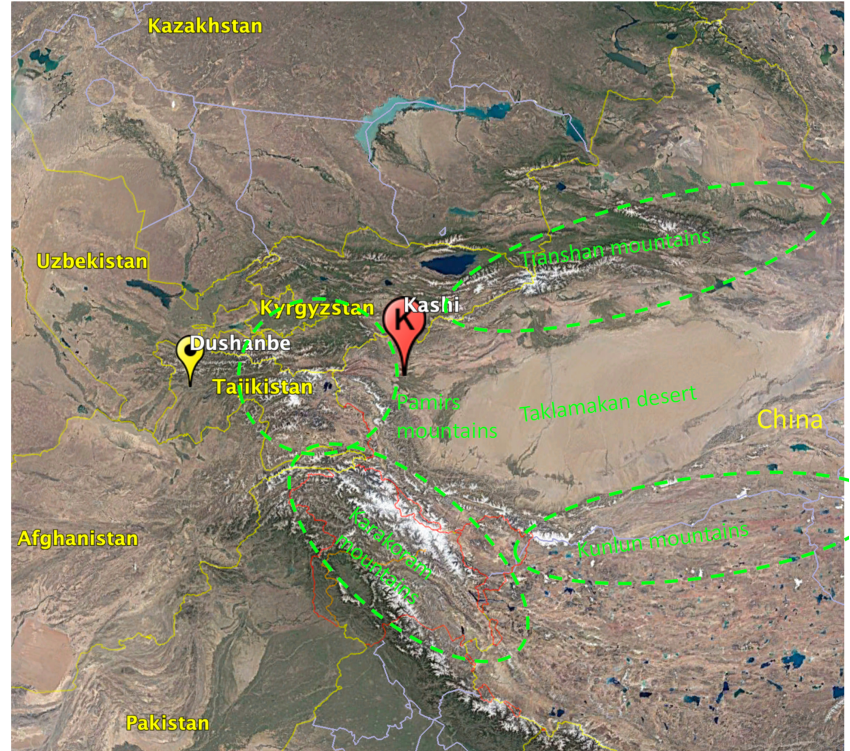

Figure 1. The location of the observation site in Kashi (at $39.51^{\circ} \mathrm{N}$, $75.93^{\circ} \mathrm{E}$ ). The observation site is about $628 \mathrm{~km}$ to the east of Dushanbe, Tajikistan $\left(38.53^{\circ} \mathrm{N}, 68.77^{\circ} \mathrm{E}\right)$. The green ellipses indicate the mountain ranges surrounding the Taklamakan desert, including the Tianshan mountains, the Pamir mountains, the Karakoram mountains, and the Kunlun and Altun mountains. (C) Google Maps 2020.

Afghanistan. Kashi features a desert climate with a big temperature difference between winter and summer. The coldest month is January with average temperatures of -10.2 $0.3^{\circ} \mathrm{C}$, and the warmest month is in July with average temperatures of $18.6-32.1{ }^{\circ} \mathrm{C}$. The annual rainfall in Kashi is about $64 \mathrm{~mm}$. The spring in Kashi is long and comes quickly. The rapidly heated surface sand in the desert could generate ascending currents which can result in frequent dust storm in springtime. This is the main reason that the field campaign was performed in springtime.

Except for desert dust, anthropogenic emissions are another important aerosol source. There are about 4.65 million inhabitants (predicted for 2017; see http://citypopulation. info/php/china-admin_c.php?adm2id=6531, last access: 11 November 2020) in the Kashi prefecture, including Kashi and 11 subordinate counties.

Kashi prefecture is a very populated region in Xinjiang with more than 1000 persons per square kilometer in the city center (Doxsey-Whitfield et al., 2015). Fine aerosol particles originating from biomass burning and local anthropogenic emissions, such as heating, traffic and industrial pollution, are an important aerosol component. Moreover, there are populated cities in the neighboring countries such as Kyrgyzstan and Tajikistan. Under favorable meteorological conditions, various aerosols, for example, pollution, could be potentially transported to Kashi and mix with dust aerosols.

\subsection{Instrumentation and methodology}

\subsubsection{Lidar system}

The multiwavelength Mie-Raman polarization lidar called LILAS (Lille Lidar Atmosphere Study) is the main instrument installed at the observation site. The lidar system has been operating in LOA (Laboratoire d'Optique Atmosphérique, Lille, France) since 2013 (Bovchaliuk et al., 2016; Veselovskii et al., 2016; Hu et al., 2019). During the DAO campaign, LILAS was transported from Lille to Kashi (and Beijing in the second session of the campaign) to perform observations. LILAS uses a Nd:YAG laser that emits at three wavelengths: 355,532 and $1064 \mathrm{~nm}$. The laser repetition rate is $20 \mathrm{~Hz}$. A Glan prism is used to clean the polarization of the laser beam. The emitting power after the Glan prism cleaning is about 70, 90 and $100 \mathrm{~mJ}$ at 355,532 and $1064 \mathrm{~nm}$, respectively. The LILAS system has three Raman channels, including 387 (vibrational-rotational), 530 (rotational) and $408 \mathrm{~nm}$ (water vapor). The use of rotational Raman at $530 \mathrm{~nm}$ provides a stronger Raman signal and relieves the dependence of the derived extinction and backscatter coefficients on the assumption of the Angström exponent (Veselovskii et al., 2015). The backscattered light is collected by a $400 \mathrm{~mm}$ Newton telescope. The incomplete overlap range of the LILAS system is about $1000-1500 \mathrm{~m}$ in distance depending on the selected field of view angle. In the receiving optics, the three elastic channels are equipped with both a perpendicular and a parallel channel with respect to the polarization plane of the emitted linearly polarized laser light in order to measure the linear depolarization ratio at three wavelengths. LILAS can provide the profiles of the $2 \alpha+3 \beta+3 \delta$ ( $\alpha$ : extinction coefficient; $\beta$ : backscatter coefficient; $\delta$ : particle linear depolarization ratio, PLDR) parameters. Benefiting from the coupled Raman channels, the extinction and backscatter coefficients at 355 and $532 \mathrm{~nm}$ are calculated using the Raman method proposed by Ansmann et al. (1992). The Raman signal generated by the radiation at $1064 \mathrm{~nm}$ is not measured by LILAS; thus, the Raman method is not applicable. The backscatter coefficient at $1064 \mathrm{~nm}$ is calculated using the Klett method, in which a vertically constant lidar ratio (extinction-to-backscatter ratio) is assumed (Klett, 1985). The particle linear depolarization ratios are derived from Eq. (1):

$\delta^{\mathrm{p}}=\frac{\left(1+\delta^{\mathrm{m}}\right) \delta^{\mathrm{v}} R-\left(1+\delta^{\mathrm{v}}\right) \delta^{\mathrm{m}}}{\left(1+\delta^{\mathrm{m}}\right) R-\left(1+\delta^{\mathrm{v}}\right)}$,

where $R$ represents the ratio of the total backscatter coefficient, involving molecules and particles, to the particle backscatter coefficient; $\delta^{\mathrm{m}}$ represents the molecular depolarization ratio; and $\delta^{\mathrm{v}}$ represents the volume linear depolarization ratio (VLDR), which equals the calibration coefficient multiplied by the ratio of the signal of the perpendicular channel to the parallel channel. The polarization calibration is performed following the $\pm 45^{\circ}$ method (Freudenthaler 
et al., 2009). During the DAO campaign, the polarization calibration was performed at least once per day.

The Ångström exponent of the extinction coefficient and backscatter coefficient are calculated with Eq. (2):

$\AA=-\frac{\log p\left(\lambda_{1}\right)-\log p\left(\lambda_{2}\right)}{\log \lambda_{1}-\log \lambda_{2}}$,

where $p(\lambda)$ represents the optical parameters, such as aerosol optical depth (AOD), extinction or backscatter coefficient at wavelength $\lambda$, and $\AA$ represents the Ångström exponent of the corresponding parameters $p(\lambda)$.

The statistical error of lidar derived parameters is estimated using the method presented in $\mathrm{Hu}$ et al. (2019). The data presented in this study are recorded at nighttime, so the background radiation is negligible. The error in the extinction and backscatter coefficients is about $10 \%$, which leads to about a $15 \%$ error in the lidar ratios at 355 and $532 \mathrm{~nm}$. The error in the backscatter coefficient at $1064 \mathrm{~nm}$ is about $20 \%$. The error in PLDR is calculated in terms of the backscatter ratio, VLDR and molecular depolarization ratio. For the data presented in this study, the error in PLDR is no greater than $15 \%$ at 532 and $1064 \mathrm{~nm}$. Therefore, we conservatively use $15 \%$ as the error in PLDR for 532 and $1064 \mathrm{~nm}$. At $355 \mathrm{~nm}$, the error of $15 \%$ still holds when dust concentration is high enough, but when the concentration drops, the error could exceed $15 \%$. In the case study, errors at $355 \mathrm{~nm}$ are calculated separately. The errors for the water vapor mixing ratio (WVMR) and relative humidity (RH) are about $20 \%$.

\subsubsection{Sun-sky photometer}

Three sun-sky photometers are deployed in the Kashi observation site. One is affiliated with AERONET (AErosol RObotic NETwork; Holben et al., 1998), and the other two are affiliated with SONET (Sun-Sky Radiometer Observation Network). SONET is a ground-based sun photometer network with the extension of a multiwavelength polarization measurement capability to provide long-term columnar atmospheric aerosol properties over China (Li et al., 2018). The three sun-sky photometers provide complementary measurements by following different measurement protocols. In all, they can measure daytime aerosol optical depth (denoted as AOD hereafter) at 340, 380, 440, 675, 870, 1020 and $1640 \mathrm{~nm}$, polarized/unpolarized sky radiances at 440,675 , 870 and $1020 \mathrm{~nm}$, and moon AOD as well. The succeeding data treatment and retrieval are performed following the protocols and standards of AERONET or SONET depending on the affiliation of the instruments.

\subsubsection{Satellite data}

Satellite data have complementary advantages due to their large spatial coverage compared to ground-based remote sensing techniques. In order to monitor dust activities in the Taklamakan desert, we use the UV aerosol index (UVAI

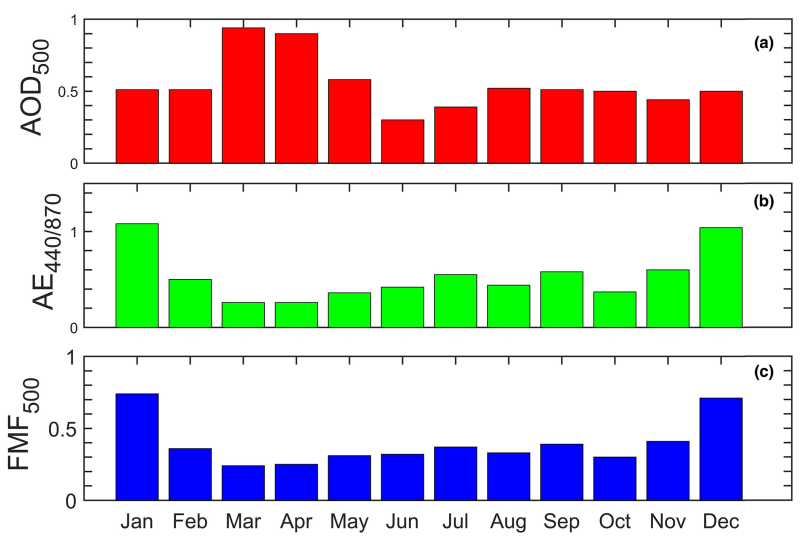

Figure 2. Monthly means of (a) the AOD at $500 \mathrm{~nm}$, (b) Ångström exponent (440-870) and (c) fine mode fraction (FMF) at $500 \mathrm{~nm}$ from 2013 to 2017 . The data are obtained from the SONET network.

hereafter) derived from the OMPS (Ozone Mapping Profiler Suite) on board the Suomi-NPP (National Polar-orbiting Partnership) satellite (Flynn et al., 2004; Seftor et al., 2014). OMPS provides full daily coverage data, and the overpass time for the Kashi region is around 06:30 UTC. The UVAI is calculated using the signal in the 340 and $380 \mathrm{~nm}$ channels (Hsu et al., 1999).

$\mathrm{UVAI}=-100 \times\left\{\log _{10}\left[\frac{I_{340}}{I_{380}}\right]_{\text {meas }}-\log _{10}\left[\frac{I_{340}}{I_{380}}\right]_{\text {calc }}\right\}$,

where $I_{340}$ and $I_{380}$ represent the backscattered radiance at 340 and $380 \mathrm{~nm}$. The subscripts "meas" and "calc" respectively represent the real measurements and model simulation in a pure Rayleigh atmosphere. By the definition of UVAI, its positive values correspond to UV-absorptive aerosols such as desert dust and carbonaceous aerosols. Hence, the UVAI from OMPS is a good parameter for monitoring the activity in the Taklamakan desert.

\subsubsection{Auxiliary data}

A radiosonde station $\left(39.47^{\circ} \mathrm{N}, 75.99^{\circ} \mathrm{N}\right)$ in Kashi is $6 \mathrm{~km}$ from the observation site. The data are accessible on the website of the Wyoming weather data website (see http:// www.weather.uwyo.edu/upperair/sounding.html, last access: 1 April 2020). The radio sounding data are recorded at 00:00 and 12:00 local time every day. They provide the vertical temperature and pressure profiles for the calculation of molecule scattering parameters in lidar data processing. The HYSPLIT (Hybrid Single-Particle Lagrangian Integrated Trajectory; Stein et al., 2015; Rolph et al., 2017) model developed by the National Oceanic and Atmospheric Administration (NOAA) Air Resources Laboratory is used for the back trajectory of the air mass and for the air mass clustering. The HYSPLIT model is driven by the $0.5^{\circ}$ gridded GDAS (Global Data Assimilation System) data and 


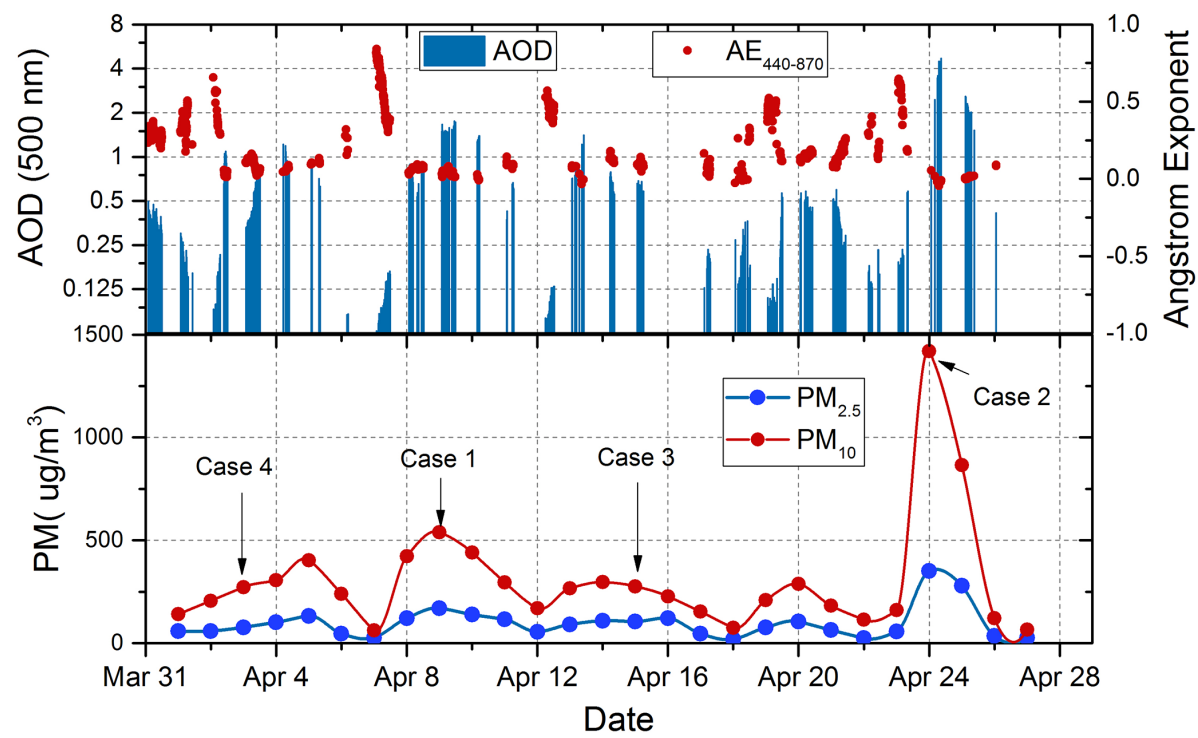

Figure 3. The AOD at $500 \mathrm{~nm}$, Ångström exponent (440-870) and daily particulate matter (in $\mu \mathrm{g} \mathrm{m}^{-3}$ ) in April 2019. The AODs are measured by the sun-sky photometer deployed at the Kashi site, and the data are stored in the SONET network. The particulate matter measurements are public data from a meteorological station $5 \mathrm{~km}$ from the observation site.

could produce the transport pathways of the air mass at different vertical levels.

Moreover, instruments measuring particulate matter (PM10 and PM2.5), gas concentration $\left(\mathrm{SO}_{2}, \mathrm{O}_{3}\right.$ and $\left.\mathrm{NO}_{x}\right)$, particle size distribution, particle scattering and absorption coefficients, and solar radiation and a cloud monitor are also deployed in the field campaign. These data contribute to relevant air quality and solar radiation studies within the frame of the DAO campaign.

\section{Results and analysis}

\subsection{Overview}

Figure 2 presents the monthly averaged AOD at $500 \mathrm{~nm}$, Ångström exponent between 440 and $870 \mathrm{~nm}$, and the FMF (fine mode fraction, the fraction of fine mode AOD to total AOD) at the Kashi site from 2013 to 2017. The data are derived from SONET. The highest AOD occurs in spring, i.e., March and April, while the lowest values occur in summer time, i.e., June and July. The Ångström exponent is positively correlated to the FMF and negatively correlated to the AOD. The lowest mean Ångström exponent occurs in March and April, indicating that dust particles are dominant due to the seasonal increase in dust activities in this period (Littmann, 1991; Qian et al., 2002). In December and January, the Ångström exponent and FMF increase significantly, which proves that fine particles are an important aerosol component in winter.

Figure 3a plots the AOD at $500 \mathrm{~nm}$ and the Ångström exponent measured during the DAO campaign in April 2019.
The AOD varies from 0.07 to 4.70 and the Angström exponent varies from 0.0 to 0.8 . For AOD greater than 0.2 , the corresponding Ångström exponent mostly falls into the range of 0.0 to 0.2 , whereas for AOD lower than 0.2, the Ångström exponent is mostly between 0.3 to 0.7 . The negative correlation between the AOD and the Ångström exponent indicates that coarse particles are the main cause for the increase in AOD. This argument is supported by the variation in the particulate matter plotted in Fig. 3b.

We select four representative cases from the nearly 1 month of lidar observations. The four cases are recorded on 3, 9, 15 and 24 April 2019. In order to distinguish "pure" Taklamakan dust observations, we define Taklamakan dust by EAE $355-532$ (Ångström exponent related to the extinction coefficient) smaller than 0.1 and PLDR 532 greater than 0.32 at $532 \mathrm{~nm}$. Polluted dust is defined by PLDR smaller than 0.30 at $532 \mathrm{~nm}$ and EAE no smaller than 0.2. Back trajectories are also used as a reference for identifying the aerosol origins. The maps of UVAI are plotted in Fig. 4. On 9 and 24 April, intense aerosol plumes were observed over the Taklamakan desert. One extreme dust event occurred on 24 April when the AOD (at $500 \mathrm{~nm}$ ) reached about 4.70 at 08:40 UTC with an instantaneous Ångström exponent of about -0.02 and visibility of about $1 \mathrm{~km}$ (see https://www.timeanddate.com/weather/ china/kashgar/historic ?month $=4 \&$ year $=2019$, last access: 9 August 2020). The $\mathrm{PM}_{10}$ increased to the monthly maximum on 24 April, reaching nearly $1500 \mu \mathrm{g} \mathrm{m}^{-3}$. It should be noted that, in this extreme case where AOD reached 4.70, the accuracy of the measured AOD may degrade because of the decreasing signal-to-noise ratio. Moreover, weak incoming solar radiation might disturb the performance of the cloud 

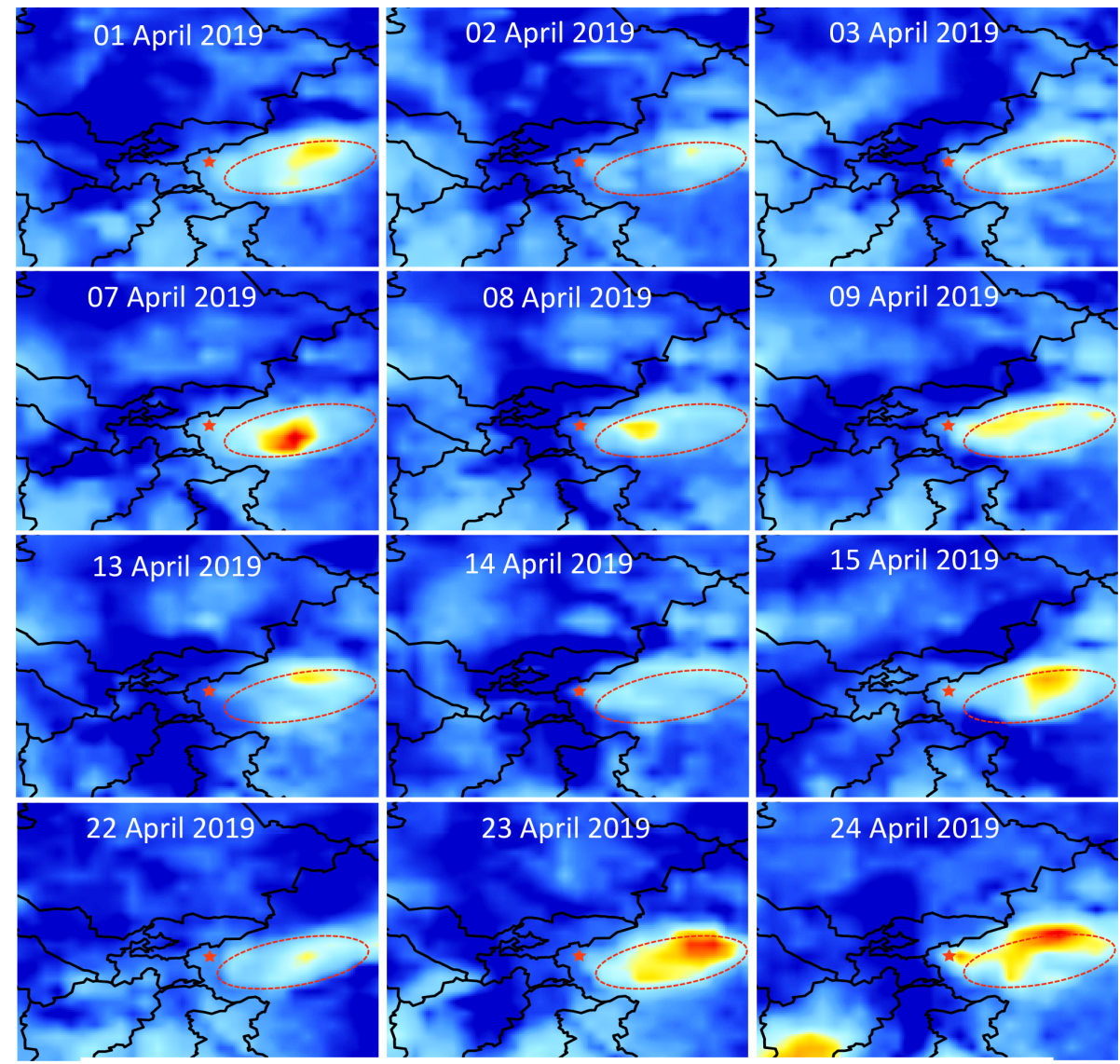

Aerosol Index

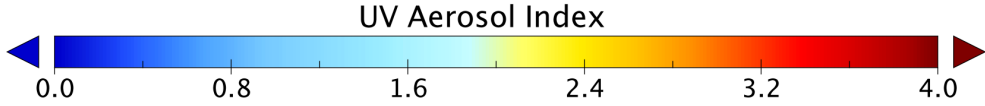

Figure 4. The UVAI derived from the OMPS instrument on board the Suomi-NPP satellite. The red star represents the location of the observation site. The dashed red ellipse represents the location of the Taklamakan desert.

screening in the quality control procedure, thus disabling the discrimination of cloud contaminated and non-contaminated measurements. On 3 and 15 April, the activity of the Taklamakan desert became less intense compared to the first two cases. The concentration of dust particles decreased, and the features of polluted dust appeared. Lidar quicklooks at $532 \mathrm{~nm}$ for the four cases are plotted in Fig. 5 .

\subsection{Case studies}

\subsubsection{Case 1: 9 April 2019}

Dust plumes over the Taklamakan desert were detected on 7 , 8 and 9 April, as shown in Fig. 4. The most intense plume in the $3 \mathrm{~d}$ appeared on 7 April with a maximum UVAI of about 4.0. On 9 April, a belt-like plume appeared in the north and northwest of the desert. Figure 5b shows the range-corrected lidar signal at $532 \mathrm{~nm}$ collected between 9 and 10 April. The boundary layer height slightly increases from 3000 to $4000 \mathrm{~m}$ during the night, and a strong backscattered lidar signal is seen below $2000 \mathrm{~m}$.
Figure 6 shows the profiles of the optical properties, WVMR and RH averaged between 17:00 and 22:00 UTC, 9 April 2019. The extinction coefficients gradually decrease with height. At $1000 \mathrm{~m}$, the extinction coefficients are greater than $0.5 \mathrm{~km}^{-1}$ and remain almost stable below $2000 \mathrm{~m}$. The RH is no more than $40 \pm 8 \%$ below $2000 \mathrm{~m}$ and rises to $60 \pm 12 \%$ at $3800 \mathrm{~m}$. The lidar ratio varies between $40 \pm 6$ and $48 \pm 7 \mathrm{sr}$ at $532 \mathrm{~nm}$ and between $55 \pm 8$ and $62 \pm 9 \mathrm{sr}$ at $355 \mathrm{~nm}$. The PLDR is about $0.32 \pm 0.05$ at $355 \mathrm{~nm}$ and $0.36 \pm 0.05$ at $532 \mathrm{~nm}$. The VLDR at $1064 \mathrm{~nm}$ is about $0.32 \pm 0.03$. The backscatter coefficient, as well as the PLDR, at $1064 \mathrm{~nm}$ is not available above $1800 \mathrm{~m}$ since the $1064 \mathrm{~nm}$ lidar signal was distorted in the upper boundary layer. We can expect that the VLDR is approximate to PLDR at $1064 \mathrm{~nm}$ in this case because the dust content is so high that molecular scattering at $1064 \mathrm{~nm}$ can be neglected. The $\mathrm{EAE}_{355-532}$ is about $-0.10 \pm 0.30$ at $800 \mathrm{~m}$ and rises to $0.10 \pm 0.30$ at $3800 \mathrm{~m}$. The $\mathrm{BAE}_{355-532}$ (Ångström exponent related to backscatter coefficient) is negative and varies from $-0.7 \pm 0.3$ to $-0.4 \pm 0.3$. Below $3000 \mathrm{~m}$, the lidar ra- 

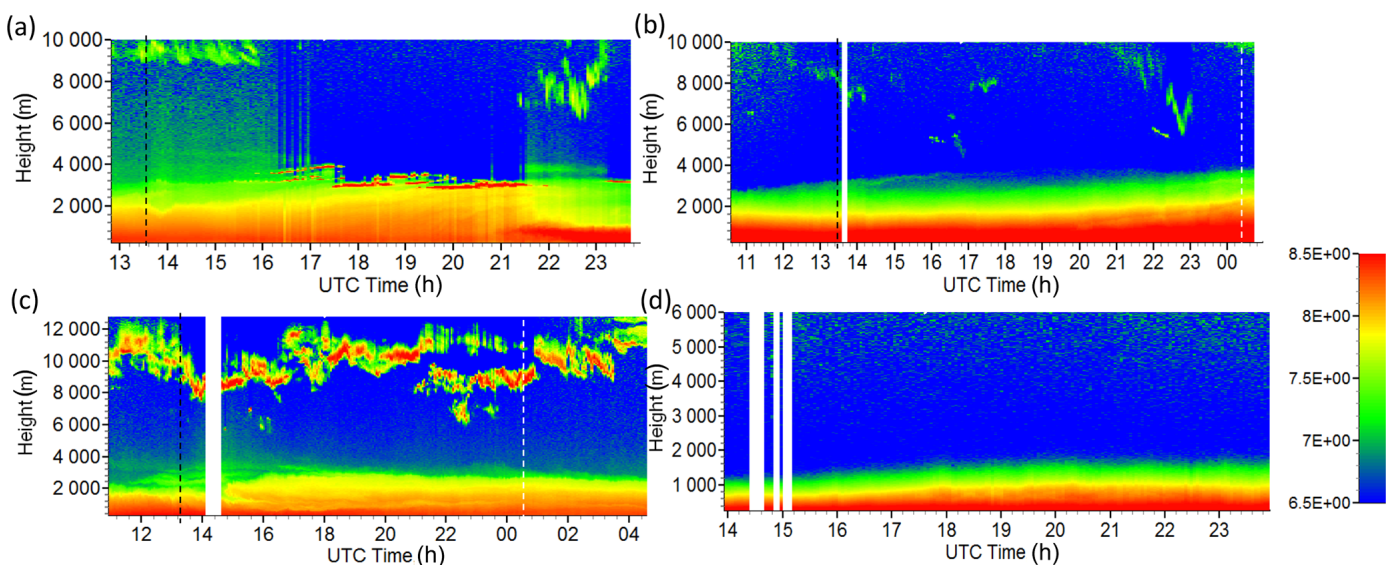

Figure 5. The quicklooks of the range-corrected lidar signal at $532 \mathrm{~nm}$ in the four cases: (a) Case 4: 3 April 2019, (b) Case 1: 9 April 2019, (c) Case 3: 15 April 2019 and (d) Case 2: 24 April 2019. The dashed black lines represent the sunset time, and the dashed white lines represent the sunrise time.

tios mildly decrease with height, while the PLDRs do not show obvious vertical variations. Above $3000 \mathrm{~m}$, the vertical variations in the lidar ratios and PLDRs become more significant. The vertical variations in the lidar ratios and PLDRs are possibly the result of particle sedimentation and/or vertically dependent particle origins.

On 9 April, the Taklamakan desert was covered by a lowpressure zone with easterly and northeasterly winds prevailing over the western part of the desert. It is a favorable condition for the elevation of dust particles. Figure 7 shows the $48 \mathrm{~h}$ back trajectory ending at 20:00 UTC for air masses at 1000,2000 and $3000 \mathrm{~m}$. The air masses at the three vertical levels originated from the Taklamakan desert. They all passed over the area where dust plumes have been observed and then diverged when approaching the rim of the desert. In the end, the air masses at 1000, 2000 and $3000 \mathrm{~m}$ arrived at the observation site from the northeast, east and southeast, respectively. The particles observed by LILAS on 9 April are fresh desert dust without long-range transport. Therefore, they could contain a large fraction of coarse-mode particles, especially giant particles (radius $>20 \mu \mathrm{m}$ ). Moreover, the back trajectories in Fig. 7 show convective strong air flows arising from below 500 to $3000 \mathrm{~m}$ within $3 \mathrm{~h}$, suggesting the possibility of large particles near the surface being lifted to higher levels.

\subsubsection{Case 2: 24 April 2019}

On 24 April, the observation site was enclosed by floating dust. In the daytime, the sky radiance dropped below the detection limit of the sun-sky photometer, so the AERONET and SONET retrievals could not be applied. A large and intense plume was first detected in the morning of 23 April 2019 (Fig. 4). On 24 April, a hot spot of UVAI appeared over the observation site. The daily average of AOD is 3.63 and the Ångström exponent is about -0.01 accord- ing to the daytime sun-sky photometer measurements. The lidar quicklook on 24 April in Fig. 5 shows that the boundary layer height rises from about 1200 to $2000 \mathrm{~m}$ from 14:00 to 24:00 UTC. Due to the high dust attenuation in the boundary layer, both sun-sky photometer and lidar can not detect whether clouds existed on 24 April.

Figure 8 plots the averaged parameters between 15:00 and 24:00 UTC, 24 April 2019. The dust layer was so thick that the laser beam could not penetrate it. The amplitude of the Raman signal dropped by 5-6 orders of magnitude in the lower $2000 \mathrm{~m}$. In this condition, we could not find an aerosolfree zone for the calibration of lidar signal; therefore, the calculation of the backscatter coefficient using Raman method is not possible, but the extinction coefficient can be derived from the Raman signal (Ansmann et al., 1992). The extinction coefficients are $1.0 \pm 0.1 \mathrm{~km}^{-1}$ at $800 \mathrm{~m}$ and increase to about $1.5 \pm 0.2 \mathrm{~km}^{-1}$ at $1500 \mathrm{~m}$. The extinction coefficient at $355 \mathrm{~nm}$ is removed above $1500 \mathrm{~m}$ because it starts to oscillate due to an insufficient signal-to-noise ratio. The extinction coefficient at $532 \mathrm{~nm}$ decreases to about $1.1 \pm 0.1 \mathrm{~km}^{-1}$ at $2000 \mathrm{~m}$. By assuming that the lidar ratios are about 55 and $45 \mathrm{sr}$ at 355 and $532 \mathrm{~nm}$, respectively, we obtain the backscatter coefficient from the extinction coefficient and then calculate the PLDRs (in Fig. 8c). The PLDR is about 0.32 at $355 \mathrm{~nm}$ and 0.37 at $532 \mathrm{~nm}$, which are rather consistent with the results in Case 1. The uncertainties of the PLDRs are not accessible because the uncertainties of the assumption of the lidar ratio are not known.

The back trajectories (not shown) indicate that dust particles (at 1000 and $2000 \mathrm{~m}$ ) originated from the northeast and east where intense dust plumes were observed on 23 and 24 April. Figure 9 shows synoptic conditions at 00:00 UTC, 23 April, and 06:00 UTC, 24 April. The meteorological conditions on 23 and 24 April are favorable for dust emission, similar to Case 1. The Taklamakan desert is enclosed by a low-pressure zone (Fig. 9a and c). The plume ob- 


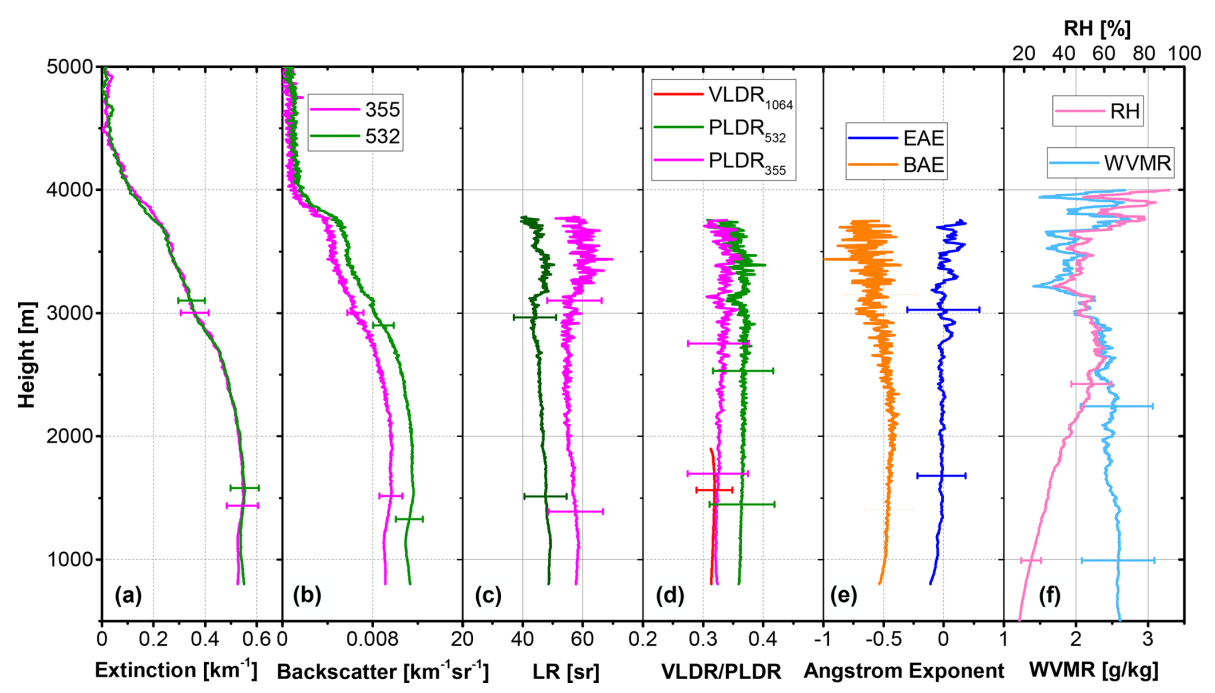

Figure 6. Case 1: lidar-derived parameters at 17:00-22:00 UTC, 9 April 2019. (a) Extinction coefficient, (b) backscattering coefficient, (c) lidar ratio, (d) PLDR/VLDR, (e) EAE $355-532$ and BAE $355-532$, and (f) WVMR and RH.

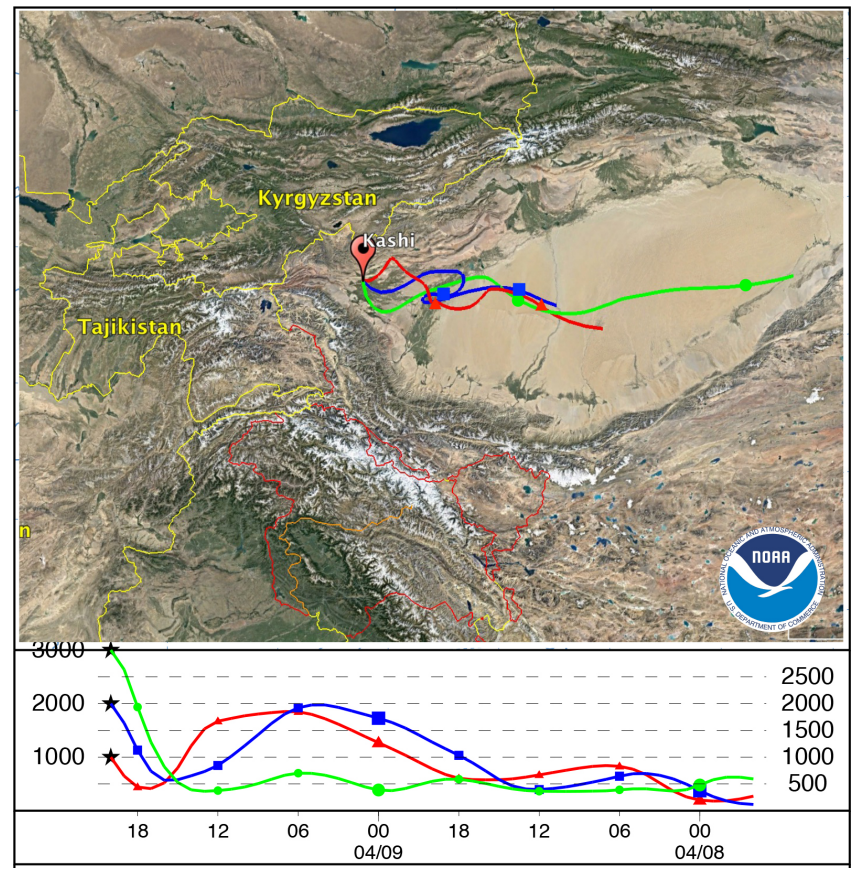

Figure 7. Case 1: the $48 \mathrm{~h}$ back trajectories ending at 20:00 UTC, 9 April 2019, for air masses at 1000, 2000 and $3000 \mathrm{~m}$. (C) Google Maps 2020.

served by OMPS on 23 April was probably lofted during the local morning. In the eastern part of the Taklamakan desert $\left(37-39^{\circ} \mathrm{N}, 83-88^{\circ} \mathrm{E}\right)$, the wind velocity at $10 \mathrm{~m}$ above ground level reaches more than $50 \mathrm{~km} \mathrm{~h}^{-1}$ (Fig. 9a) and at $850 \mathrm{hPa}$ level the maximum wind velocity reaches $90 \mathrm{~km} \mathrm{~h}^{-1}$ (Fig. 9b). The high wind velocity near the surface and large vertical wind gradient help elevate dust particles from the

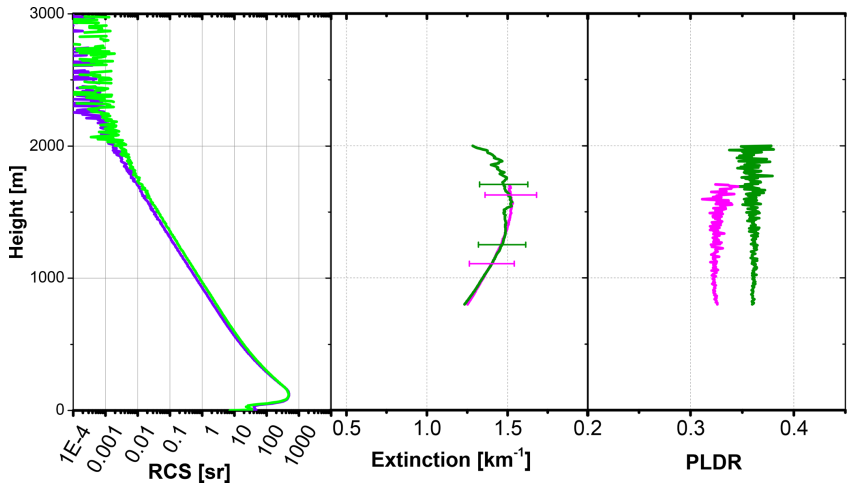

Figure 8. Case 2: lidar-derived parameters at 15:00-24:00 UTC, 24 April 2019. (a) The Raman lidar signals at 530 and $387 \mathrm{~nm}$, (b) the extinction coefficients at 355 and $532 \mathrm{~nm}$, and (c) the PLDRs at 355 and $532 \mathrm{~nm}$.

surface into the atmosphere. On 23 and 24 April, easterly and northeasterly wind were prevalent in the desert region, thus blowing the lifted dust particles to the observation site. Case 2 is a more severe manifestation of Case 1 regarding the intensity of the dust loading. In both cases, the observed dust particles originated from nearby dust source. Compared to typical depolarization ratios in worldwide dust observations, which are $0.23-0.30$ at $355 \mathrm{~nm}$ and $0.30-0.35$ at $532 \mathrm{~nm}$, the depolarization ratios we obtained in the two cases are relatively higher (Veselovskii et al., 2016; Freudenthaler et al., 2009; Hofer et al., 2017; Hofer et al., 2020). While previous observation sites were mostly not as close to the dust source as in our campaign, the differences are probably due to the fraction of coarse-mode particles that remain in our dust observation. Burton et al. (2015) also observed dust particles near the source in North America and reported PLDR of 0.37 
at $532 \mathrm{~nm}$, which is consistent with our result. However, the PLDR at $355 \mathrm{~nm}$ measured by Burton et al. (2015) is about 0.24 , which is lower than what we obtained.

\subsubsection{Case 3: 15 April 2019}

On 15 April, the daily mean AOD on 15 April was 0.63, and the Ångström exponent was about 0.10 . Compared to the previous two cases, the Ångström exponent increases obviously. The boundary layer height started to increase at 15:00 UTC and stayed at $3500 \mathrm{~m}$ during the night of 15 April. Cirrus clouds were continuously present during the period of lidar measurement (Fig. 5c). The lidar-derived profiles between 18:00 and 20:00 UTC are plotted in Fig. 10. The extinction coefficients in the boundary layer are about $0.15 \mathrm{~km}^{-1}$ and decrease to almost zero at $3500 \mathrm{~m}$. The $\mathrm{RH}$ increases up to $60 \% \pm 12 \%$ at $2200 \mathrm{~m}$. Below this height, the lidar ratio, PLDR, EAE and $\mathrm{BAE}$ are almost stable. The lidar ratio is about $51 \pm 8 \mathrm{sr}$ at $355 \mathrm{~nm}$ and $45 \pm 7 \mathrm{sr}$ at $532 \mathrm{~nm}$. The PLDRs at 355, 532 and $1064 \mathrm{~nm}$ are around $0.32 \pm 0.07$, $0.34 \pm 0.05$ and $0.31 \pm 0.05$, respectively. The $\mathrm{EAE}_{355-532}$ is about $0.02 \pm 0.30$, showing a gentle increase with height, and the $\mathrm{BAE}_{355-532}$ is about $-0.29 \pm 0.30$. Above $2200 \mathrm{~m}$, the $\mathrm{RH}$ starts to increase and reaches its maximum, i.e., $80 \% \pm 16 \%$, at $2800 \mathrm{~m}$. The $\mathrm{EAE}_{355-532}$ and $\mathrm{BAE}_{355-532}$ increase to $0.10 \pm 0.30$ and $-0.06 \pm 0.30$, respectively. In contrast, the lidar ratios and PLDRs decrease and reach their minima at about $2800 \mathrm{~m}$. The lidar ratio is about $40 \pm 6 \mathrm{sr}$ at 2400-2800 m with a weak spectral dependence, and the PLDRs are about $0.23 \pm 0.06$ at $355 \mathrm{~nm}, 0.26 \pm 0.04$ at $532 \mathrm{~nm}$ and $0.24 \pm 0.03$ at $1064 \mathrm{~nm}$. It should be noted that the backscatter coefficient at $1064 \mathrm{~nm}$ is performed using the Klett method with an assumption of the lidar ratio equal $40 \mathrm{sr}$ (Klett, 1985).

Dust activities were observed by the OMPS on 13 and 15 April 2019 (Fig. 4), while the intensity was less strong than in cases 1 and 2 , and the distance between the dust plume and the observation site was farther. The $48 \mathrm{~h}$ back trajectories ending at 19:00 UTC are shown in Fig. 11. Air masses at the three vertical levels (1000, 2000 and $3000 \mathrm{~m}$ ) originated from the eastern part of the Taklamakan desert, where no intense dust activities had been observed by OMPS in the recent $3 \mathrm{~d}$. It explains the decrease in dust content in the boundary layer. When dust loading decreases, the impact of fine mode particles emerges. The changes in EAE, BAE, PLDR and lidar ratios above $2200 \mathrm{~m}$ are clear evidence of polluted dust. The pollution could be lifted up from the ground in the local area by convection or be transported from another area. Additionally, the RH above $2500 \mathrm{~m}$ is about $60 \% \pm 12 \%-80 \% \pm 16 \%$, which could lead to the hygroscopic growth of some aerosol species. Pure dust is regarded as hydrophobic aerosols because its compounds are insoluble, but when mixed with hygroscopic aerosol species, for example, nitrate, the ensemble of aerosol mixture could become hygroscopic. The fine mode particles can be hydropho- bic or hydroscopic depending on their chemical compositions (Carrico et al., 2003; Shi et al., 2008; Pan et al., 2009). In this case, there is no clear evidence indicating the occurrence of hygroscopic growth or the mixing state of dust and pollution particles.

\subsubsection{Case 4: 3 April 2019}

The daily mean AOD on 3 April is 0.16, and the Angström exponent is about 0.11 . The boundary layer height is about 3000 to $4000 \mathrm{~m}$, rising slightly during the night of 3-4 April. Starting from 16:30 UTC, some liquid cloud layers occurred at the top of the boundary layer (Fig. 5a). Figure 12 shows the profiles derived from lidar observations at 14:00-16:00 UTC, 3 April. The extinction coefficients decrease from about $0.28 \pm 0.03 \mathrm{~km}^{-1}$ at $1000 \mathrm{~m}$ to about $0.10 \pm 0.01 \mathrm{~km}^{-1}$ at $3000 \mathrm{~m}$, with $\mathrm{EAE}_{355-532}\left(\mathrm{BAE}_{355-532}\right)$ increasing from $0.01 \pm 0.30(-0.38 \pm 0.3)$ to $0.28 \pm 0.30(0.02 \pm 0.30)$. Below $2100 \mathrm{~m}$, the lidar ratios are about $45 \pm 7 \mathrm{sr}$ at $532 \mathrm{~nm}$ and $51 \pm 8 \mathrm{sr}$ at $355 \mathrm{~nm}$. The PLDRs are about $0.35 \pm 0.05$ at $532 \mathrm{~nm}$ and $0.32 \pm 0.05$ at $1064 \mathrm{~nm}$ and $0.28-0.32 \pm 0.07$ at $355 \mathrm{~nm}$. Between 2100 and $3000 \mathrm{~m}$, the variation in lidar ratios is not monotonic. At $2500 \mathrm{~m}$, the lidar ratios reach the minimum of $38 \pm 6 \mathrm{sr}$ at $532 \mathrm{~nm}$ and $42 \pm 6 \mathrm{sr}$ at $355 \mathrm{~nm}$, and the PLDRs are about $0.27 \pm 0.06$ at $355 \mathrm{~nm}$ and $0.33 \pm 0.05$ at $532 \mathrm{~nm}$. Both the lidar ratios and PLDRs in the 2400 $2800 \mathrm{~m}$ range are very consistent with the properties of Central Asian dust reported by Hofer et al. (2017) and Hofer et al. (2020). Above $2500 \mathrm{~m}$, the lidar ratios and the RH (as well as WVMR) increase again, and PLDRs decrease. At $3000 \mathrm{~m}$, the PLDR at $532 \mathrm{~nm}$ drops below 0.30, suggesting that aerosols are different from those in the lower boundary layer. The signatures of lidar ratio, RH and PLDR are possibly linked to the occurrence of polluted dust particles. In addition, long-range transported dust could also possess such PLDRs due to the deposition of big particles in the transport. This case is classified as polluted dust because the PLDR below 0.30 at $532 \mathrm{~nm}$ and the increase in WVMR (as well as $\mathrm{RH})$ and $\mathrm{EAE}_{355-532}$ at the boundary layer top fit the characteristics of polluted dust better.

Figure 13 plots the $72 \mathrm{~h}$ back trajectories for 1000,2000 and $3000 \mathrm{~m}$. Air masses at 1000 and $2000 \mathrm{~m}$ are from the Taklamakan desert, while the air mass at $3000 \mathrm{~m}$ is from Central Asia. It corroborates the similarities of the lidar ratios and PLDRs between the measurements in Hofer's studies (Hofer et al., 2017; Hofer et al., 2020) and in our study. When extending the trajectory duration to $96 \mathrm{~h}$, the results (not plotted) suggest that the air mass at $3000 \mathrm{~m}$ originated from northern Africa. This result suggests that dust particles observed in Kashi may have a long-transport aerosol component. The air mass clustering based on $24 \mathrm{~h}$ back trajectories (not shown) indicates that about $52 \%$ of the air mass at $3000 \mathrm{~m}$ is from northern Africa and the Arabian Peninsula. At $3500 \mathrm{~m}$, this proportion increases to $74 \%$, and there is also a fraction of an air mass coming from Europe. The complex- 

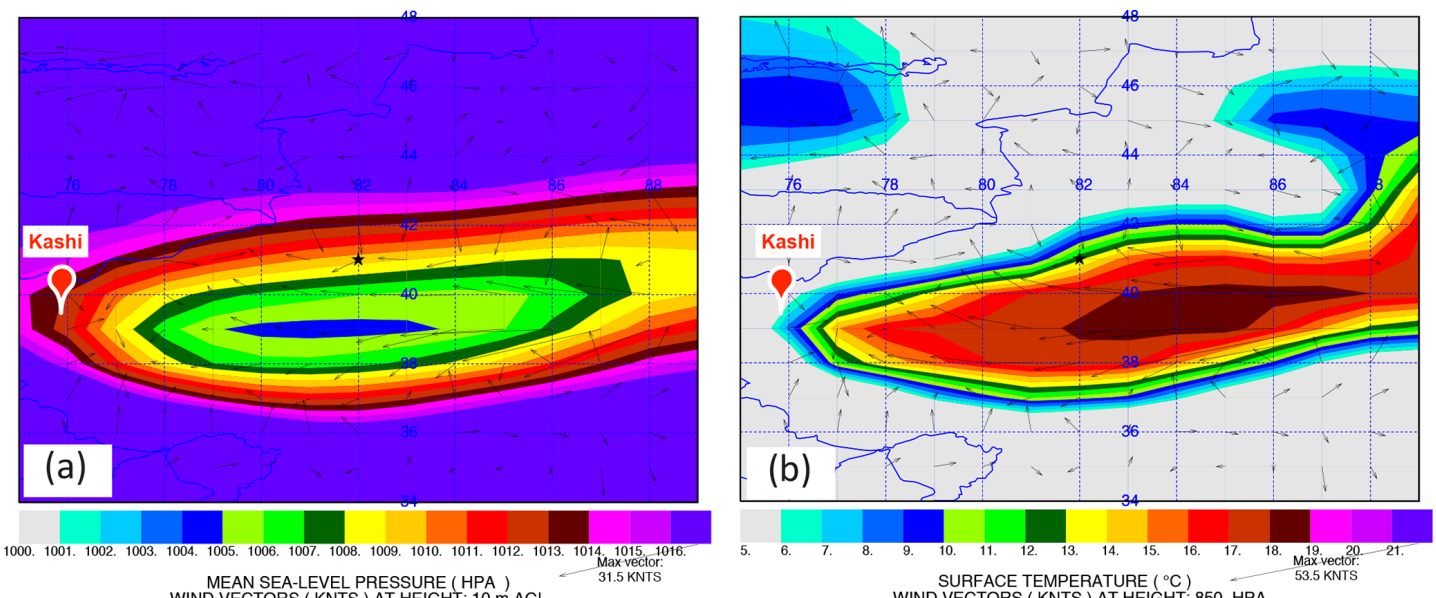

MEAN SEA-LEVEL PRESSURE (HPA )
WIND VECTORS (KNTS) AT HEIGHT: 10 m AG

SURFACE TEMPERATURE $\left({ }^{\circ} \mathrm{C}\right.$ )
WIND VECTORS ( KNTS ) AT HEIGHT: 850 . HPA
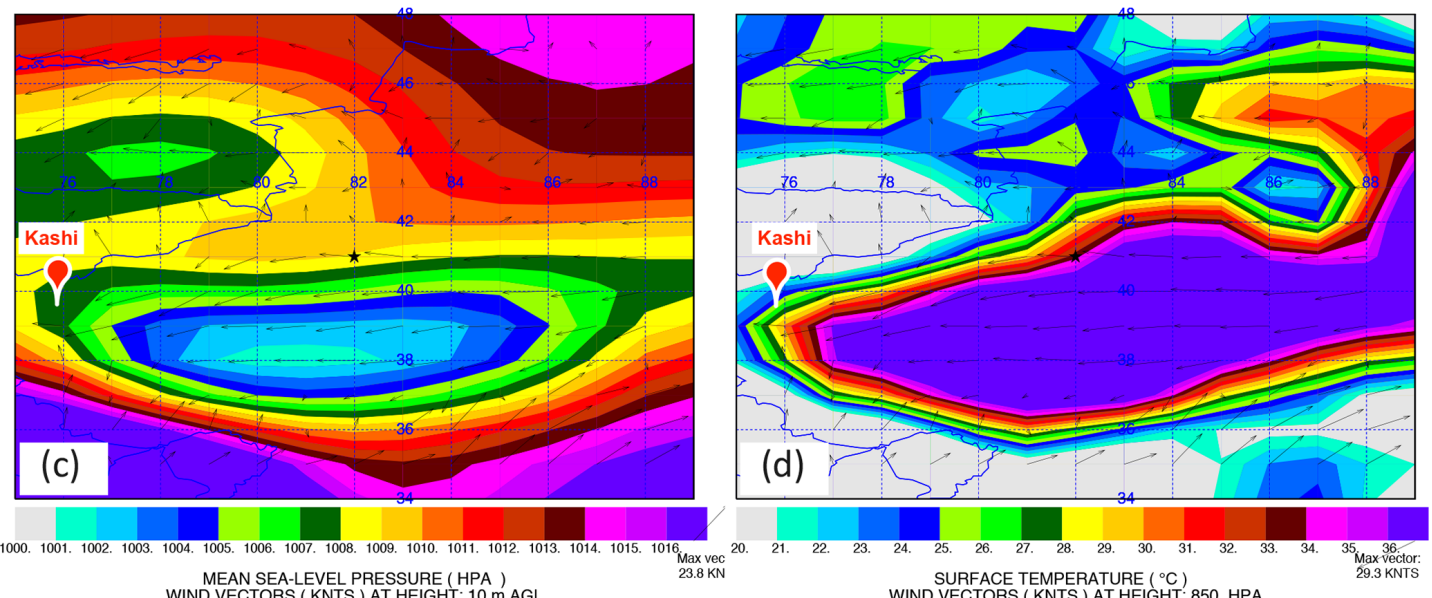

1000. 1001. 1002. 1003. 1004. 1005. 1006. 1007. 1008. 1009. 1010. 1011. 1012. 1013. 1014. 1015. $1016 \mathrm{Max} \mathrm{vec}_{23.8 \mathrm{KN}}^{20}$ WIND VECTORS ( KNTS ) AT HEIGHT: $10 \mathrm{~m}$ AG

SURFACE TEMPERATURE $\left({ }^{\circ} \mathrm{C}\right)$
WIND VECTORS ( KNTS ) AT HEIGHT: 850 . HPA

Figure 9. Case 2: the synoptic condition at 00:00 UTC, 23 April (a, b), and 06:00 UTC, 24 April (c, d), 2019. The data are obtained from the $1^{\circ}$ GDAS archived meteorological data. (a, c) The mean sea level pressure at the surface overlaid with wind vectors at $10 \mathrm{~m}$ above the ground level. (b, d) The temperature at $2 \mathrm{~m}$ vertical level overlaid with wind vectors at $850 \mathrm{hPa}$ vertical level.

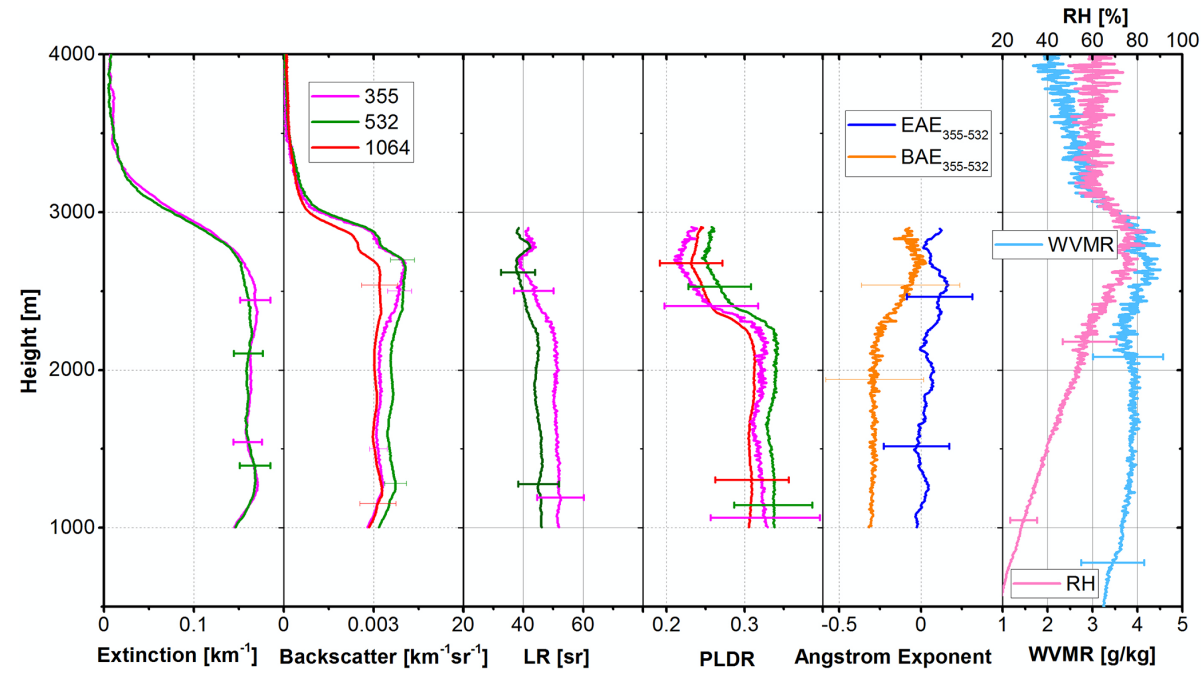

Figure 10. Case 3: lidar-derived parameters at 18:00-20:00 UTC, 15 April 2019. (a) Extinction coefficient, (b) backscattering coefficient, (c) lidar ratio, (d) PLDR, (e) EAE $355-532$ and $\mathrm{BAE}_{355-532}$, and (f) WVMR and RH. 


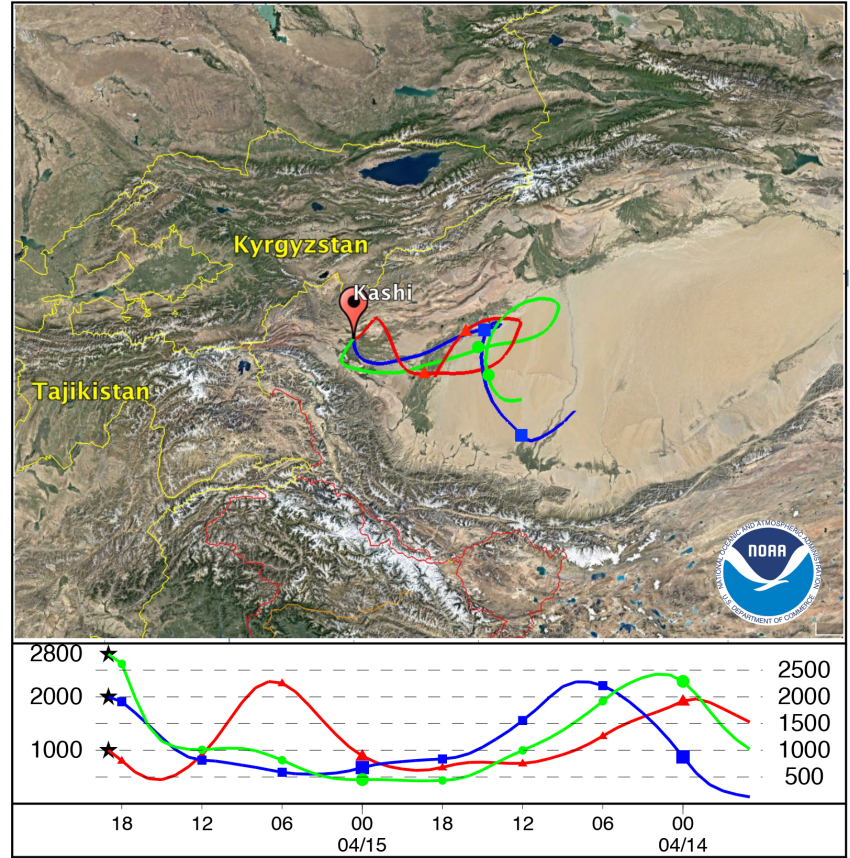

Figure 11. Case 3: the $48 \mathrm{~h}$ back trajectories ending at 19:00 UTC, 15 April 2019, for air masses at 1000, 2000 and $2800 \mathrm{~m}$. (C) Google Maps 2020.

ity in the aerosol sources in the transport pathways explains the variability of aerosol properties in the upper boundary layer in Case 4.

\section{Discussion}

\subsection{Aerosol source}

The optical parameters in the four cases are summarized in Table 2. During the campaign, dust is undoubtedly the predominant component. In dust events (Case 1 and Case 2), dust particles are lifted from the Taklamakan desert by the low-pressure system along with strong wind and then blown to the observation site by the easterly or northeasterly wind. In dry deposition, coarse-mode particles, especially giant particles, settle down faster than the fine mode dust particles. In many previous campaigns, the observed dust particles have undergone long-range transport, ranging from several hundreds or thousands of kilometers (Dieudonné et al., 2015; Murayama et al., 2004; Veselovskii et al., 2016; Ansmann et al., 2003; Haarig et al., 2017; Hofer et al., 2017; Hofer et al., 2020; Filioglou et al., 2020), while the transport distance is much shorter in the DAO campaign. Thus, the observed dust particles in the DAO campaign are more likely to contain a large fraction of coarse-mode and giant particles, which is an important difference in our observations compared to most previous observations. Moreover, the mineral composition of dust is size-dependent. In the study of Sa-
Table 1. Daily averaged AOD at $500 \mathrm{~nm}$ and Ångström exponent (AE; between 440 and $870 \mathrm{~nm}$ ) measured by the sun-sky photometer in daytime. The values on the right side of " \pm " represent the standard deviation of the values on the left side.

\begin{tabular}{lrr}
\hline & AOD $_{500}$ & $\mathrm{AE}_{440-870}$ \\
\hline Case 1, 9 April & $1.48 \pm 0.10$ & $0.04 \pm 0.02$ \\
Case 2, 24 April & $3.63 \pm 1.28$ & $-0.01 \pm 0.03$ \\
Case 3, 15 April & $0.63 \pm 0.03$ & $0.10 \pm 0.02$ \\
Case 4, 3 April & $0.49 \pm 0.16$ & $0.11 \pm 0.03$ \\
\hline
\end{tabular}

haran dust, Kandler et al. (2009, 2011) found a tendency of a higher quartz content in larger particles, but a significant fraction of sulfate was found in the size range smaller than $1 \mu \mathrm{m}$. The iron-bearing minerals, which are linked to dust absorption, are more concentrated in the fraction with a radius smaller than $2.0 \mu \mathrm{m}$. The difference in the size distribution could lead to a difference in mineralogical composition and chemical properties (Ryder et al., 2018; Di Biagio et al., 2019).

The influence of pollution is not clearly seen in the dust storms. However, when the activities of the Taklamakan desert wane and the dust concentration becomes lower, the impact of pollution emerges. Observations in Case 3 clearly demonstrate the contrast of dust in the lower boundary layer and polluted dust particles at the boundary layer top. During the 1 month campaign, the traces of pollution, featured with increased $\mathrm{EAE}_{355-532}$ and decreased PLDRs, are frequently observed. The evidence of pollution in Taklamakan dust has been found in previous in situ measurements. Huang et al. (2010) sampled aerosol particles in springtime at the Tazhong site, which is located in the north rim of the Taklamakan desert, and found that the As element was moderately enriched. The As element is a tracer of pollution, originating probably from coal burning. It is also found that the concentration of sulfate in Taklamakan dust is at a high level. The increased concentration of sulfate in the Taklamakan dust could be related to its provenance in the Taklamakan desert because the desert is speculated to have been ocean 57 millions years ago (Sun and Liu, 2006). Sulfate could also come from anthropogenic emissions, for example, the uptake of $\mathrm{SO}_{2}$ gases. Iwasaka et al. (2003) examined aerosol samples using electron microscopy in Dunhuang, China, which is downwind of transported Taklamakan dust. They found that mineral dust is the main component in the coarse-mode aerosols, while in the fine mode, ammonia sulfate, which is mainly from anthropogenic emissions, is the major component. These studies indicate that the Taklamakan dust near the source region have been contaminated by other aerosols of anthropogenic origin. It is in agreement with our analysis; however, in this study, we can not clarify the exact involved aerosol species and the mixing state in the polluted dust. In our study, polluted dust mostly appeared at the bound- 


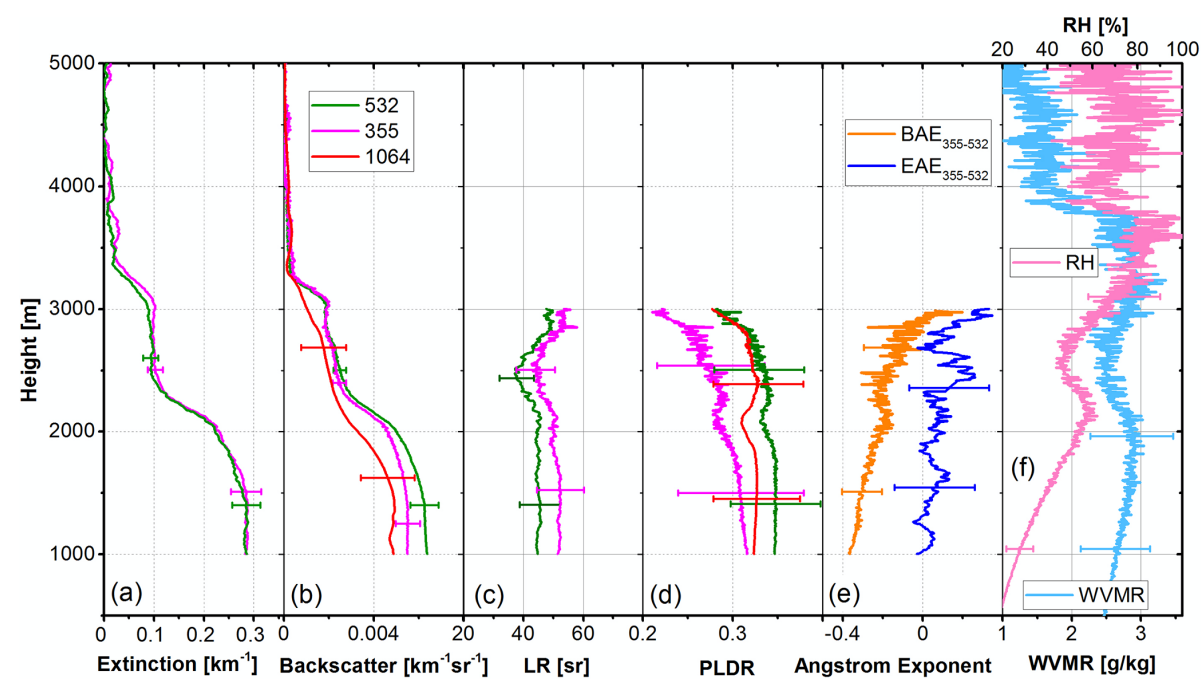

Figure 12. Case 4: lidar-derived parameters at 14:00-16:00 UTC, 3 April 2019. (a) Extinction coefficient, (b) backscattering coefficient, (c) lidar ratio, (d) PLDR, (e) EAE $355-532$ and BAE $355-532$, and (f) WVMR and RH.

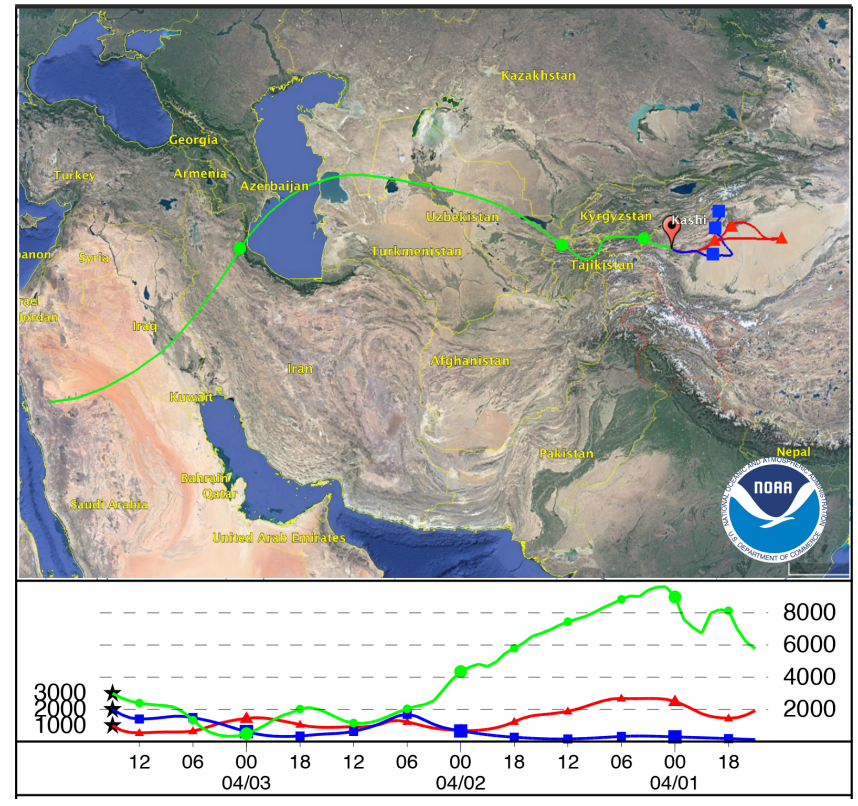

Figure 13. Case 4: the $72 \mathrm{~h}$ back trajectories ending at 15:00 UTC, 3 April 2019, for air masses at 1000, 2000 and $3000 \mathrm{~m}$. (C) Google Maps 2020.

ary layer top, which agrees with the finding of Iwasaka et al. (2003). These fine particles are possibly lifted by convective air flow and then remain at higher altitudes as bigger particles settle down.

Long-range transported aerosols are another possible aerosol origin in Kashi. Based on model simulations, some previous studies have reported intercontinental dust transport from northern Africa and the Middle East to East Asia (Park et al., 2005; Tanaka et al., 2005; Sugimoto et al., 2019). Fig- ure 14 plots the air mass clustering for three different vertical levels in April 2019. The contribution of air masses from Central Asia, the Middle East, Europe and northern Africa always exists, and the influence increases with height. At $1000 \mathrm{~m}$, the main aerosol source is from the Taklamakan desert and accounts for about $73 \%$. At $3000 \mathrm{~m}$, air masses from Central Asia, the Middle East and northern Africa account for about $51 \%$, and the air mass from Europe is about $2 \%$. At $4000 \mathrm{~m}$, the air mass from Taklamakan occupies only $29 \%$, and the rest are from Central Asia, the Middle East and northern Africa. The west-to-east air mass transport is associated with the midlatitude westerlies, which are a continuous force for air mass transport (Yumimoto et al., 2009; Yu et al., 2019). In Case 4, we observed dust signatures that differ from Taklamakan dust but correspond well with the results from Hofer et al. (2017) and Hofer et al. (2020) in Dushanbe. Nevertheless, there are various aerosol sources in the intercontinental transport pathway, such as dust from northern Africa, the Middle East and Central Asia and pollution and biomass burning from eastern Europe. Moreover, the aerosol properties could be modified during the transport. Hence, it is difficult to find out the exact aerosol types using lidar observations.

\subsection{Lidar ratio and depolarization ratio}

We found that, for Taklamakan dust, the lidar ratios are about $45 \pm 7 \mathrm{sr}$ at $532 \mathrm{~nm}$ and $51-56 \pm 8 \mathrm{sr}$ at $355 \mathrm{~nm}$. The PLDRs are about $0.28-0.32 \pm 0.07$ at $355 \mathrm{~nm}, 0.36 \pm 0.05$ at $532 \mathrm{~nm}$ and $0.31 \pm 0.05$ at $1064 \mathrm{~nm}$.

Table 3 presents an overview of the lidar ratios and PLDRs of Asian, Saharan and American dust in previous publications. Jin et al. (2010) derived a lidar ratio of $42 \pm 3 \mathrm{sr}$ at $532 \mathrm{~nm}$ for Taklamakan dust, which agrees well with our 

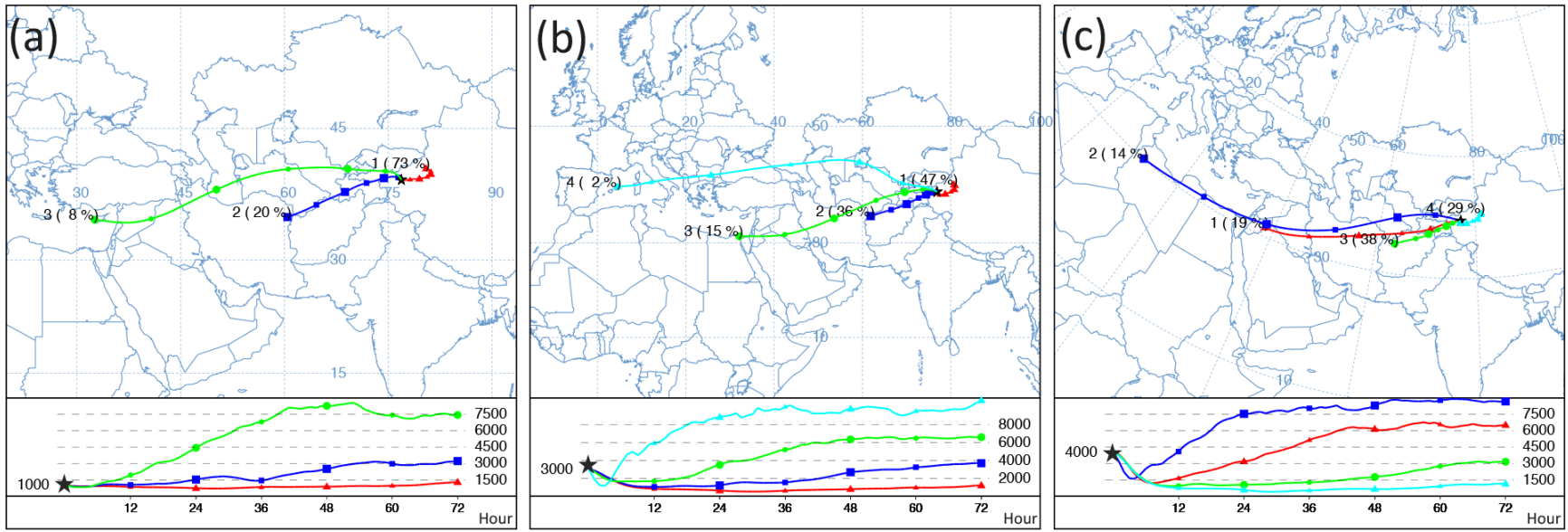

Figure 14. The clustering of air masses in April 2019. The clustering is performed using HYSPLIT and based on back trajectories with a $2 \mathrm{~h}$ time resolution and $72 \mathrm{~h}$ duration. (a) $1000 \mathrm{~m}$, (b) $3000 \mathrm{~m}$ and (c) $4000 \mathrm{~m}$.

Table 2. A summary of optical properties derived from lidar observations in the case studies. The values before the " \pm " symbol represent the mean in the range of the layer height. The values after the " \pm " symbol represent the statistical error of the values before the symbol.

\begin{tabular}{|c|c|c|c|c|c|c|}
\hline \multirow[b]{2}{*}{ Layer height (m) } & \multirow{2}{*}{$\begin{array}{l}\text { Case 1: } \\
\text { dust haze } \\
\text { 15:00-16:00 } \\
9 \text { April } \\
800-3800\end{array}$} & \multirow{2}{*}{$\begin{array}{l}\text { Case 2: } \\
\text { dust storm } \\
\text { 15:00-16:00 } \\
\text { 24 April } \\
800-2000\end{array}$} & \multicolumn{2}{|c|}{$\begin{array}{c}\text { Case 3: } \\
\text { polluted dust } \\
\text { 15:00-16:00 } \\
\text { 15 April }\end{array}$} & \multirow{2}{*}{\multicolumn{2}{|c|}{$\begin{array}{c}\begin{array}{c}\text { Case 4: } \\
\text { polluted dust } \\
\text { 15:00-16:00 } \\
3 \text { April } \\
1500-3000\end{array}\end{array}$}} \\
\hline & & & $1000-2200$ & $2400-2800$ & & \\
\hline $\mathrm{PLDR}_{355}$ & $0.32 \pm 0.05$ & $0.32 \pm 0.05$ & $0.32 \pm 0.07$ & $0.23 \pm 0.06$ & $0.30-0.32 \pm 0.07$ & $0.21 \pm 0.05-0.29 \pm 0.07$ \\
\hline $\mathrm{PLDR}_{532}$ & $0.36 \pm 0.05$ & $0.36 \pm 0.05$ & $0.34 \pm 0.05$ & $0.26 \pm 0.03$ & $0.35 \pm 0.05$ & $0.28 \pm 0.04-0.34 \pm 0.05$ \\
\hline (V)PLDR 1064 & $0.31 \pm 0.04^{\mathrm{a}}$ & - & $0.31 \pm 0.04$ & $0.24 \pm 0.03$ & $0.32 \pm 0.05$ & $0.28 \pm 0.04-0.33 \pm 0.05$ \\
\hline $\mathrm{LR}_{355}(\mathrm{sr})$ & $56 \pm 8$ & $55^{\mathrm{b}}$ & $51 \pm 8$ & $42 \pm 6$ & $51 \pm 8$ & $43 \pm 6-57 \pm 8$ \\
\hline $\mathrm{LR}_{532}(\mathrm{sr})$ & $46 \pm 7$ & $45^{\mathrm{b}}$ & $45 \pm 7$ & $40 \pm 6$ & $45 \pm 7$ & $38 \pm 6-49 \pm 8$ \\
\hline $\mathrm{EAE}_{355-532}$ & $-0.01 \pm 0.30$ & $0.01 \pm 0.30$ & $0.02 \pm 0.30$ & $0.10 \pm 0.30$ & $0.02 \pm 0.30$ & $0.14 \pm 0.30-0.30 \pm 0.30$ \\
\hline $\mathrm{BAE}_{355-532}$ & $-0.51 \pm 0.30$ & - & $-0.29 \pm 0.30$ & $-0.06 \pm 0.30$ & $-0.29 \pm 0.30$ & $-0.13 \pm 0.30-0.20 \pm 0.30$ \\
\hline $\mathrm{RH}(\%)$ & $20 \pm 4-60 \pm 12$ & $10 \pm 2-20 \pm 4$ & $30 \pm 6-60 \pm 12$ & $80 \pm 16$ & $20 \pm 4-60 \pm 12$ & $45 \pm 9-70 \pm 14$ \\
\hline WVMR $\left(\mathrm{g} \mathrm{kg}^{-1}\right)$ & $2.2 \pm 0.5$ & - & $3.5 \pm 7$ & $4.0 \pm 0.8$ & $2.7 \pm 0.6$ & $2.7 \pm 0.6$ \\
\hline
\end{tabular}

${ }^{a} \mathrm{PLDR}_{1064}$ is not available in this case but $\mathrm{VLDR}_{1064}$ is. We assume $\mathrm{VLDR}_{1064} \approx \mathrm{PLDR}_{1064}$ considering aerosol scattering is much stronger than molecular scattering.

b 55 and $45 \mathrm{sr}$ are assumed lidar ratios based on the results in Case 1.

results. The observation site in Jin et al. (2010) was very close to Kashi; however, their results were based on the observations of an elastic lidar, so it requires the assumption of vertically independent lidar ratio and complementary measurements. Observations obtained from other Asian sites show mean lidar ratios in the range of 40-50 sr (39$43 \mathrm{sr})$ and PLDR in the range of 0.17-0.29 $(0.20-0.35)$ at $355 \mathrm{~nm}(532 \mathrm{~nm})$ (Dieudonné et al., 2015; Murayama et al., 2004; Hofer et al., 2017; Hofer et al., 2020; Filioglou et al., 2020). Both the lidar ratios and PLDRs are slightly lower than the results we obtained from Taklamakan dust. Case 4 in this study shows the coincidence of characteristics of Taklamakan dust in the lower boundary layer and Central Asian dust (Hofer et al., 2017) in the upper boundary layer. This co- incidence proves that the differences of lidar ratios and PLDRs between Taklamakan dust and Central Asian dust are not caused by a systematic bias of measurements in two different lidar systems but that the two types of dust are optically different.

The large fraction of coarse-mode and giant particles in Taklamakan dust are supposed to be the main reasons responsible for this difference. Moreover, differences of the dust mineralogical composition in various geographical locations may also contribute to the differences in optical properties. For example, observations in SAMUM and SHADOW campaigns revealed lower PLDRs and higher lidar ratios in Saharan dust compared to Asian dust (Groß et al., 2011; Veselovskii et al., 2016, 2020). It could be explained by the 
Table 3. A review of dust lidar ratios and particle linear depolarization ratios in literatures. The values of lidar ratios and PLDRs, as well as their errors, are based on the results in the references. Error estimates are not provided if their are not available in the original publication.

\begin{tabular}{|c|c|c|c|c|c|c|c|}
\hline \multirow{2}{*}{$\begin{array}{l}\text { Dust } \\
\text { source }\end{array}$} & \multirow{2}{*}{$\begin{array}{l}\text { Observation } \\
\text { site }\end{array}$} & \multicolumn{3}{|c|}{ PLDRs } & \multicolumn{2}{|c|}{ LRs } & \multirow{2}{*}{ Reference } \\
\hline & & 355 & 532 & 1064 & 355 & 532 & \\
\hline \multirow{8}{*}{$\begin{array}{l}\text { Saharan } \\
\text { dust }\end{array}$} & Ouarzazate $^{\mathrm{a}}$ & - & 0.30 & - & - & $38-50$ & Esselborn et al. (2009) \\
\hline & Ouarzazate $^{\mathrm{d}}$ & - & - & - & $53-55$ & $53-55$ & Tesche et al. (2009) \\
\hline & Cape Verde & $0.24-0.27$ & $0.29-0.31$ & - & $48-70$ & $48-70$ & Groß et al. (2011) \\
\hline & M'Bour ${ }^{b}$ & - & $0.34 \pm 0.05$ & - & $68 \pm 10$ & $50 \pm 8$ & Veselovskii et al. (2016) \\
\hline & M'Bour ${ }^{\mathrm{e}}$ & - & $0.32 \pm 0.05$ & - & $55-60 \pm 9$ & $55-60 \pm 8$ & Veselovskii et al. (2020) \\
\hline & Leipzig & - & $0.15-0.25$ & & $50-90$ & $40-80$ & Ansmann et al. (2003) \\
\hline & Barbados & $0.26 \pm 0.03$ & $0.27 \pm 0.01$ & - & $53 \pm 5$ & $56 \pm 7$ & Groß et al. (2015) \\
\hline & Barbados & $0.25 \pm 0.03$ & $0.28 \pm 0.02$ & $0.23 \pm 0.02$ & $40-60$ & $40-60$ & Haarig et al. (2017) \\
\hline \multirow{9}{*}{$\begin{array}{l}\text { Asian } \\
\text { dust }\end{array}$} & Aksu & - & - & - & - & $42 \pm 3$ & Jin et al. (2010) \\
\hline & Japan & - & 0.20 & - & 49 & 43 & Murayama et al. (2004) \\
\hline & Kazan & $0.23 \pm 0.02$ & - & - & $43 \pm 14$ & - & Dieudonné et al. (2015) \\
\hline & Omsk & $0.17 \pm 0.02$ & - & - & $50 \pm 13$ & - & \\
\hline & Dushanbe $^{c}$ & $0.23 \pm 0.01$ & $0.35 \pm 0.01$ & _- & $47 \pm 2$ & $43 \pm 3$ & Hofer et al. (2017) \\
\hline & Dushanbe $^{\mathrm{f}}$ & $0.29 \pm 0.01$ & $0.35 \pm 0.01$ & - & $40 \pm 1$ & $39 \pm 1$ & \\
\hline & Dushanbe ${ }^{g}$ & $0.24 \pm 0.03$ & $0.33 \pm 0.04$ & - & $43 \pm 3$ & $39 \pm 4$ & Hofer et al. (2020) \\
\hline & UAE & $0.25 \pm 0.02$ & $0.31 \pm 0.02$ & - & $45 \pm 5$ & $42 \pm 5$ & Filioglou et al. (2020) \\
\hline & Kashi & $\begin{array}{l}0.28 \pm 0.07- \\
0.32 \pm 0.07\end{array}$ & $0.36 \pm 0.05$ & $0.31 \pm 0.05$ & $\begin{array}{l}51 \pm 8- \\
56 \pm 8\end{array}$ & $45 \pm 7$ & This study \\
\hline \multirow{2}{*}{$\begin{array}{l}\text { American } \\
\text { dust }\end{array}$} & Chihuahuan & $0.24 \pm 0.05$ & $0.37 \pm 0.02$ & $0.38 \pm 0.01$ & - & - & Burton et al. (2015) \\
\hline & Pico de Orizaba & - & $0.33 \pm 0.02$ & $0.40 \pm 0.01$ & - & - & Burton et al. (2015) \\
\hline
\end{tabular}

${ }^{\text {a }}$ HSRL measurements; ${ }^{\mathrm{b}} 29$ March 2015 in the dry season; ${ }^{\mathrm{c}}$ extreme dust case on 8 August 2015 ; ${ }^{\mathrm{d}}$ Raman lidar measurement; ${ }^{\mathrm{e}} 23-24$ April 2015 in the transition period;

${ }^{\mathrm{f}}$ most extreme dust case on 14 July $2016 ;^{\mathrm{g}}$ statistical results estimated from 17 dust cases with PLDR $532>0.31$.

argument that Saharan dust tends to be more absorbing than Asian dust due to its relatively higher content of iron oxides (Di Biagio et al., 2019).

Recent studies concluded that there are similarities in dust size and shape parameters which explain the relatively uniform distribution of dust PLDRs for globally distributed dust sources. Nevertheless, the variability in dust properties should still be considered. PLDRs as high as Taklamakan dust have even been found in several previous studies. Burton et al. (2015) found comparable PLDR of 0.37 at $532 \mathrm{~nm}$ in American dust near the source, but at $355 \mathrm{~nm}$, the PLDR was about 0.24 , falling into the typical range of dust. Sakai et al. (2010) derived PLDR (at $532 \mathrm{~nm}$ ) of 0.39 for Asian and Saharan dust with a high number concentration of supermicrometer particles, while for submicrometer particles, the PLDR was about $0.14-0.17$. It proves that an increase in big particle concentration could strongly increase the PLDR. Miffre et al. (2016) measured artificial dust samples with mainly submicrometer particles and derived PLDRs of 0.37 at $355 \mathrm{~nm}$ and 0.36 at $532 \mathrm{~nm}$. The high PLDRs are likely caused by the sharp edges and corners produced in the fabrication of dust samples. In naturally formed dust particles, these corners or edges may be trimmed by aeolian or fluvial erosion. This could be one reason why previous dust observations never found PLDRs greater than 0.30 at $355 \mathrm{~nm}$, while near the source and in heavy dust event, we suppose that the lifted dust may contain a fraction of big and morphologically complicated particles which have strong depolarizing effects. Since Taklamakan dust observations in the source region are quite rare, more observational data are needed for complementing the dataset of dust characteristics.

\section{Conclusions}

The first session of the DAO campaign was conducted in Kashi, China, in April 2019. The objective of the DAO campaign is to provide a comprehensive characterization of Taklamakan dust using multiwavelength Mie-Raman lidar measurements. During the nearly 1 month campaign, we found that dust particles originating mainly from the Taklamakan desert are the dominant aerosol component in springtime in Kashi, while the influence of fine mode particles needs to also be considered. Kashi is a populated region, and pollution emitted from anthropogenic activities is very likely the main component in fine mode aerosols. Additionally, air mass clustering using the HYSPLIT model suggests that longrange transported aerosols from Africa, Europe, the Middle East and Central Asia could be the potential source of aerosols in Kashi.

This study provides the first characterization of the spectral lidar ratios and PLDRs of the Taklamakan dust. One dis- 
tinct feature of Taklamakan dust is its relatively high PLDRs compared to other Asian dust and Saharan dust. We suppose this difference is related to the coarse-mode and giant particles that remain in the Taklamakan dust near the source region. The results fill the gap of the characterization of Taklamakan dust and provide reference for succeeding studies and for implementing the climate modeling. This study also points out the importance of considering the dust mixing with pollution in climate modeling. Our results show that, in the most dusty season of the year and at an observation site $150 \mathrm{~km}$ from the desert, the observed Taklamakan dust has already been polluted. Pollution could alter the optical and microphysical properties of dust particles, thus influencing the direct radiative forcing. Moreover, polluted dust could modify the cloud formation process by acting as cloud condensation nuclei and ice nuclei, which impose indirect influence on the earth's radiation budget and long-term climate change. The DAO campaign offers a nice collection of measurements relevant to cloud-dust interactions, which will be presented in the next step.

Data availability. The satellite data from OMPS and AIRS can be found in NASA's GES DIS service center. The meteorological data, GDAS data and the HYSPLIT dispersion model are available at the NOAA ARL site (https://ready.arl.noaa.gov/HYSPLIT.php, last access: 1 February 2020; Stein et al., 2015). All the other data presented in this study are available upon any request.

Author contributions. The project was supervised by PG and ZL. $\mathrm{QH}, \mathrm{TP}$ and IV were in charge of the lidar operation and maintenance. QH, IV and HW performed the data analysis. QH wrote the paper. KL provided the sun-sky photometer data. MK helped in the lidar operation and instrument preparation.

Competing interests. The authors declare that they have no conflict of interest.

Special issue statement. This article is part of the special issue "Satellite and ground-based remote sensing of aerosol optical, physical, and chemical properties over China". It is not associated with a conference.

Acknowledgements. We acknowledge the colleagues at the Institute of Remote Sensing and Digital Earth for their kind help and for the financial support. We thank the colleagues from the GPI RAS (Prokhorov General Physics Institute of the Russian Academy of Sciences), Service National d'Observation PHOTONS/AERONETEARLINET, a component of the ACTRIS infrastructure, the ESA/IDEAS + and Labex CaPPA projects, and IAP (Institute of Atmospheric Physics) for the participation and the efforts they have made for the campaign. The Russian Science Foundation (project
16-17-10241) is acknowledged for providing lidar data processing algorithms.

Financial support. This research has been supported by the Agence Nationale de la Recherche (grant no. ANR-11-LABX-0005).

Review statement. This paper was edited by Matthias Tesche and reviewed by two anonymous referees.

\section{References}

Ansmann, A., Riebesell, M., Wandinger, U., Weitkamp, C., Voss, E., Lahmann, W., and Michaelis, W.: Combined Raman elasticbackscatter lidar for vertical profiling of moisture, aerosol extinction, backscatter, and lidar ratio, Appl. Phys. B, 55, 18-28, 1992.

Ansmann, A., Bösenberg, J., Chaikovsky, A., Comerón, A., Eckhardt, S., Eixmann, R., Freudenthaler, V., Ginoux, P., Komguem, L., Linné, H., et al.: Long-range transport of Saharan dust to northern Europe: The 11-16 October 2001 outbreak observed with EARLINET, J. Geophys. Res.-Atmos., 108, 4783 , https://doi.org/10.1029/2003JD003757, 2003.

Boucher, O., Randall, D., Artaxo, P., Bretherton, C., Feingold, G., Forster, P., Kerminen, V.-M., Kondo, Y., Liao, H., Lohmann, U., Rasch, P., Satheesh, S. K., Sherwood, S., Stevens, B., and Zhang, X. Y.: Clouds and aerosols, in: Climate change 2013: the physical science basis. Contribution of Working Group I to the Fifth Assessment Report of the Intergovernmental Panel on Climate Change, 571-657, Cambridge University Press, 2013.

Bovchaliuk, V., Goloub, P., Podvin, T., Veselovskii, I., Tanre, D., Chaikovsky, A., Dubovik, O., Mortier, A., Lopatin, A., Korenskiy, M., and Victori, S.: Comparison of aerosol properties retrieved using GARRLiC, LIRIC, and Raman algorithms applied to multi-wavelength lidar and sun/sky-photometer data, Atmos. Meas. Tech., 9, 3391-3405, https://doi.org/10.5194/amt-9-33912016, 2016.

Burton, S. P., Hair, J. W., Kahnert, M., Ferrare, R. A., Hostetler, C. A., Cook, A. L., Harper, D. B., Berkoff, T. A., Seaman, S. T., Collins, J. E., Fenn, M. A., and Rogers, R. R.: Observations of the spectral dependence of linear particle depolarization ratio of aerosols using NASA Langley airborne High Spectral Resolution Lidar, Atmos. Chem. Phys., 15, 13453-13473, https://doi.org/10.5194/acp-15-13453-2015, 2015.

Campbell, J. R., Reid, J. S., Westphal, D. L., Zhang, J., Hyer, E. J., and Welton, E. J.: CALIOP aerosol subset processing for global aerosol transport model data assimilation, IEEE J. Select. Top. Appl. Earth Observ. Remote Sens., 3, 203-214, 2010.

Carrico, C. M., Kus, P., Rood, M. J., Quinn, P. K., and Bates, T. S.: Mixtures of pollution, dust, sea salt, and volcanic aerosol during ACE-Asia: Radiative properties as a function of relative humidity, J. Geophys. Res.-Atmos., 108, 8650, https://doi.org/10.1029/2003JD003405, 2003.

Di Biagio, C., Formenti, P., Balkanski, Y., Caponi, L., Cazaunau, M., Pangui, E., Journet, E., Nowak, S., Andreae, M. O., Kandler, K., Saeed, T., Piketh, S., Seibert, D., Williams, E., and Doussin, J.-F.: Complex refractive indices and single-scattering albedo of 
global dust aerosols in the shortwave spectrum and relationship to size and iron content, Atmos. Chem. Phys., 19, 15503-15531, https://doi.org/10.5194/acp-19-15503-2019, 2019.

Dieudonné, E., Chazette, P., Marnas, F., Totems, J., and Shang, X.: Lidar profiling of aerosol optical properties from Paris to Lake Baikal (Siberia), Atmos. Chem. Phys., 15, 5007-5026, https://doi.org/10.5194/acp-15-5007-2015, 2015.

Doxsey-Whitfield, E., MacManus, K., Adamo, S. B., Pistolesi, L., Squires, J., Borkovska, O., and Baptista, S. R.: Taking advantage of the improved availability of census data: a first look at the gridded population of the world, version 4, Appl. Geogr., 1, 226234, 2015.

Engelstaedter, S., Tegen, I., and Washington, R.: North African dust emissions and transport, Earth-Sci. Rev., 79, 73-100, 2006.

Esselborn, M., Wirth, M., Fix, A., Weinzierl, B., Rasp, K., Tesche, M., and Petzold, A.: Spatial distribution and optical properties of Saharan dust observed by airborne high spectral resolution lidar during SAMUM 2006, Tellus B Chem. Phys. Meteorol., 61, 131143, 2009.

Filioglou, M., Giannakaki, E., Backman, J., Kesti, J., Hirsikko, A., Engelmann, R., O’Connor, E., Leskinen, J. T. T., Shang, X., Korhonen, H., Lihavainen, H., Romakkaniemi, S., and Komppula, M.: Optical and geometrical aerosol particle properties over the United Arab Emirates, Atmos. Chem. Phys., 20, 8909-8922, https://doi.org/10.5194/acp-20-8909-2020, 2020.

Flynn, L. E., Homstein, J., and Hilsenrath, E.: The ozone mapping and profiler suite (OMPS). The next generation of US ozone monitoring instruments, in: Geoscience and Remote Sensing Symposium, IGARSS'04, Proceedings, 2004 IEEE International, Vol. 1, 155 pp., 2004.

Freudenthaler, V., Esselborn, M., Wiegner, M., Heese, B., Tesche, M., Ansmann, A., Müller, D., Althausen, D., Wirth, M., Fix, A., Ehret, G., Knippertz, P., Toledano, C., Gasteiger, J., Garhammer, M., and Seefeldner, M.: Depolarization ratio profiling at several wavelengths in pure Saharan dust during SAMUM 2006, Tellus B, 61, 165-179, 2009.

Ginoux, P., Prospero, J. M., Gill, T. E., Hsu, N. C., and Zhao, M.: Global-scale attribution of anthropogenic and natural dust sources and their emission rates based on MODIS Deep Blue aerosol products, Rev. Geophys., 50, RG3005, https://doi.org/10.1029/2012RG000388, 2012.

Groß, S., Tesche, M., Freudenthaler, V., Toledano, C., Wiegner, M., Ansmann, A., Althausen, D., and Seefeldner, M.: Characterization of Saharan dust, marine aerosols and mixtures of biomassburning aerosols and dust by means of multi-wavelength depolarization and Raman lidar measurements during SAMUM 2, Tellus B Chem. Phys. Meteorol., 63, 706-724, 2011.

Groß, S., Freudenthaler, V., Schepanski, K., Toledano, C., Schäfler, A., Ansmann, A., and Weinzierl, B.: Optical properties of long-range transported Saharan dust over Barbados as measured by dual-wavelength depolarization Raman lidar measurements, Atmos. Chem. Phys., 15, 11067-11080, https://doi.org/10.5194/acp-15-11067-2015, 2015.

Haarig, M., Ansmann, A., Althausen, D., Klepel, A., Groß, S., Freudenthaler, V., Toledano, C., Mamouri, R.-E., Farrell, D. A., Prescod, D. A., Marinou, E., Burton, S. P., Gasteiger, J., Engelmann, R., and Baars, H.: Triple-wavelength depolarizationratio profiling of Saharan dust over Barbados during SALTRACE in 2013 and 2014, Atmos. Chem. Phys., 17, 10767-10794, https://doi.org/10.5194/acp-17-10767-2017, 2017.

Hofer, J., Althausen, D., Abdullaev, S. F., Makhmudov, A. N., Nazarov, B. I., Schettler, G., Engelmann, R., Baars, H., Fomba, K. W., Müller, K., Heinold, B., Kandler, K., and Ansmann, A.: Long-term profiling of mineral dust and pollution aerosol with multiwavelength polarization Raman lidar at the Central Asian site of Dushanbe, Tajikistan: case studies, Atmos. Chem. Phys., 17, 14559-14577, https://doi.org/10.5194/acp-17-145592017, 2017.

Hofer, J., Ansmann, A., Althausen, D., Engelmann, R., Baars, H., Fomba, K. W., Wandinger, U., Abdullaev, S. F., and Makhmudov, A. N.: Optical properties of Central Asian aerosol relevant for spaceborne lidar applications and aerosol typing at 355 and $532 \mathrm{~nm}$, Atmos. Chem. Phys., 20, 9265-9280, https://doi.org/10.5194/acp-20-9265-2020, 2020.

Holben, B. N., Eck, T. F., Slutsker, I., Tanre, D., Buis, J. P., Setzer, A., Vermote, E., Reagan, J. A., Kaufman, Y. J., Nakajima, T., Lavenu, F., Jankowiak, I. and Smirnov, A.: AERONET - A federated instrument network and data archive for aerosol characterization, Remote Sens. Environ., 66, 1-16, 1998.

Hsu, N. C., Herman, J., Torres, O., Holben, B., Tanre, D., Eck, T., Smirnov, A., Chatenet, B., and Lavenu, F.: Comparisons of the TOMS aerosol index with Sun-photometer aerosol optical thickness: Results and applications, J. Geophys. Res.-Atmos., 104, 6269-6279, 1999.

Hu, Q., Goloub, P., Veselovskii, I., Bravo-Aranda, J.-A., Popovici, I. E., Podvin, T., Haeffelin, M., Lopatin, A., Dubovik, O., Pietras, C., Huang, X., Torres, B., and Chen, C.: Long-rangetransported Canadian smoke plumes in the lower stratosphere over northern France, Atmos. Chem. Phys., 19, 1173-1193, https://doi.org/10.5194/acp-19-1173-2019, 2019.

Huang, J., Minnis, P., Chen, B., Huang, Z., Liu, Z., Zhao, Q., Yi, Y., and Ayers, J. K.: Long-range transport and vertical structure of Asian dust from CALIPSO and surface measurements during PACDEX, J. Geophys. Res.-Atmos., 113, D23212, https://doi.org/10.1029/2008JD010620, 2008.

Huang, K., Zhuang, G., Li, J., Wang, Q., Sun, Y., Lin, Y., and Fu, J. S.: Mixing of Asian dust with pollution aerosol and the transformation of aerosol components during the dust storm over China in spring 2007, J. Geophys. Res.-Atmos., 115, D00K13, https://doi.org/10.1029/2009JD013145, 2010.

Huneeus, N., Schulz, M., Balkanski, Y., Griesfeller, J., Prospero, J., Kinne, S., Bauer, S., Boucher, O., Chin, M., Dentener, F., Diehl, T., Easter, R., Fillmore, D., Ghan, S., Ginoux, P., Grini, A., Horowitz, L., Koch, D., Krol, M. C., Landing, W., Liu, X., Mahowald, N., Miller, R., Morcrette, J.-J., Myhre, G., Penner, J., Perlwitz, J., Stier, P., Takemura, T., and Zender, C. S.: Global dust model intercomparison in AeroCom phase I, Atmos. Chem. Phys., 11, 7781-7816, https://doi.org/10.5194/acp11-7781-2011, 2011.

Iwasaka, Y., Shi, G.-Y., Yamada, M., Matsuki, A., Trochkine, D., Kim, Y., Zhang, D., Nagatani, T., Shibata, T., Nagatani, M., et al.: Importance of dust particles in the free troposphere over the Taklamakan Desert: electron microscopic experiments of particles collected with a balloonborne particle impactor at Dunhuang, China, J. Geophys. Res.-Atmos., 108, 8664, https://doi.org/10.1029/2002JD003270, 2003. 
Iwasaka, Y., Li, J., Shi, G.-Y., Kim, Y., Matsuki, A., Trochkine, D., Yamada, M., Zhang, D., Shen, Z., and Hong, C.: Mass transport of background Asian dust revealed by balloon-borne measurement: dust particles transported during calm periods by westerly from Taklamakan desert, in: Advanced environmental monitoring, pp. 121-135, Springer, the Netherlands, 2008.

Jin, Y., Kai, K., Shibata, T., Zhang, K., and Zhou, H.: Validation of the dust layer structure over the Taklimakan Desert, China by the CALIOP space-borne lidar using ground-based lidar, Sola, 6 , 121-124, 2010.

Kai, K., Nagata, Y., Tsunematsu, N., Matsumura, T., Kim, H.-S., Matsumoto, T., Hu, S., Zhou, H., Abo, M., and Nagai, T.: The Structure of the Dust Layer over the Taklimakan Deser during the Dust Storm in April 2002 as Observed Using a Depolarization Lidar, J. Meteorol. Soc. JPN II, 86, 1-16, 2008.

Kandler, K., Schütz, L., Deutscher, C., Ebert, M., Hofmann, H., Jäckel, S., Jaenicke, R., Knippertz, P., Lieke, K., Massling, A., et al.: Size distribution, mass concentration, chemical and mineralogical composition and derived optical parameters of the boundary layer aerosol at Tinfou, Morocco, during SAMUM 2006, Tellus B Chem. Phys. Meteorol., 61, 32-50, 2009.

Kandler, K., Lieke, K., Benker, N., Emmel, C., Küpper, M., MüllerEbert, D., Ebert, M., Scheuvens, D., Schladitz, A., Schütz, L., et al.: Electron microscopy of particles collected at Praia, Cape Verde, during the Saharan Mineral Dust Experiment: particle chemistry, shape, mixing state and complex refractive index, Tellus B Chem. Phys. Meteorol., 63, 475-496, 2011.

Kanji, Z. A., Ladino, L. A., Wex, H., Boose, Y., BurkertKohn, M., Cziczo, D. J., and Krämer, M.: Overview of Ice Nucleating Particles, Meteorol. Monogr., 58, 1.1-1.33, https://doi.org/10.1175/AMSMONOGRAPHS-D-16-0006.1, 2017.

Klett, J. D.: Lidar inversion with variable backscatter/extinction ratios, Appl. Opt., 24, 1638-1643, 1985.

Li, Z., Xu, H., Li, K., Li, D., Xie, Y., Li, L., Zhang, Y., Gu, X., Zhao, W., Tian, Q., et al.: Comprehensive study of optical, physical, chemical, and radiative properties of total columnar atmospheric aerosols over China: an overview of sun-sky radiometer observation network (SONET) measurements, B. Am. Meteorol. Soc., 99, 739-755, 2018.

Littmann, T.: Dust storm frequency in Asia: climatic control and variability, Int. J. Climatol., 11, 393-412, 1991.

Liu, Z., Sugimoto, N., and Murayama, T.: Extinction-to-backscatter ratio of Asian dust observed with high-spectral-resolution lidar and Raman lidar, Appl. Opt., 41, 2760-2767, 2002.

Miffre, A., Mehri, T., Francis, M., and Rairoux, P.: UV-VIS depolarization from Arizona Test Dust particles at exact backscattering angle, Journal of Quant. Spectrosc. Rad. Transf., 169, 79-90, 2016.

Murayama, T., Müller, D., Wada, K., Shimizu, A., Sekiguchi, M., and Tsukamoto, T.: Characterization of Asian dust and Siberian smoke with multi-wavelength Raman lidar over Tokyo, Japan in spring 2003, Geophys. Res. Lett., 31, L23103, https://doi.org/10.1029/2004GL021105, 2004.

Pan, X. L., Yan, P., Tang, J., Ma, J. Z., Wang, Z. F., Gbaguidi, A., and Sun, Y. L.: Observational study of influence of aerosol hygroscopic growth on scattering coefficient over rural area near Beijing mega-city, Atmos. Chem. Phys., 9, 7519-7530, https://doi.org/10.5194/acp-9-7519-2009, 2009.
Park, C. B., Sugimoto, N., Matsui, I., Shimizu, A., Tatarov, B., Kamei, A., Lee, C. H., Uno, I., Takemura, T., and Westphal, D. L.: Long-range transport of Saharan dust to east Asia observed with lidars, Sola, 1, 121-124, 2005.

Petrov, M. P. and Alitto, G. S.: Takla Makan Desert, available at: https://www.britannica.com/place/Takla-Makan-Desert (last access: 11 November 2020), 2019.

Qian, W., Quan, L., and Shi, S.: Variations of the dust storm in China and its climatic control, J. Climate, 15, 1216-1229, 2002.

Reed, K. A., Bacmeister, J. T., Huff, J. J. A., Wu, X., Bates, S. C., and Rosenbloom, N. A.: Exploring the Impact of Dust on North Atlantic Hurricanes in a High-Resolution Climate Model, Geophys. Res. Lett., 46, 1105-1112, 2019.

Rolph, G., Stein, A., and Stunder, B.: Real-time environmental applications and display system: Ready, Environ. Modell. Softw., 95, 210-228, 2017.

Ryder, C. L., Marenco, F., Brooke, J. K., Estelles, V., Cotton, R., Formenti, P., McQuaid, J. B., Price, H. C., Liu, D., Ausset, P., Rosenberg, P. D., Taylor, J. W., Choularton, T., Bower, K., Coe, H., Gallagher, M., Crosier, J., Lloyd, G., Highwood, E. J., and Murray, B. J.: Coarse-mode mineral dust size distributions, composition and optical properties from AER-D aircraft measurements over the tropical eastern Atlantic, Atmos. Chem. Phys., 18, 17225-17257, https://doi.org/10.5194/acp-18-172252018, 2018.

Sakai, T., Nagai, T., Zaizen, Y., and Mano, Y.: Backscattering linear depolarization ratio measurements of mineral, sea-salt, and ammonium sulfate particles simulated in a laboratory chamber, Appl. Opt., 49, 4441-4449, 2010.

Seftor, C., Jaross, G., Kowitt, M., Haken, M., Li, J., and Flynn, L.: Postlaunch performance of the Suomi National Polar-orbiting Partnership Ozone Mapping and Profiler Suite (OMPS) nadir sensors, J. Geophys. Res.-Atmos., 119, 4413-4428, 2014.

Sekiyama, T. T., Tanaka, T. Y., Shimizu, A., and Miyoshi, T.: Data assimilation of CALIPSO aerosol observations, Atmos. Chem. Phys., 10, 39-49, https://doi.org/10.5194/acp-10-39-2010, 2010.

Shi, Z., Zhang, D., Hayashi, M., Ogata, H., Ji, H., and Fujiie, W.: Influences of sulfate and nitrate on the hygroscopic behaviour of coarse dust particles, Atmos. Environ., 42, 822-827, 2008.

Stein, A., Draxler, R. R., Rolph, G. D., Stunder, B. J., Cohen, M., and Ngan, F.: NOAA's HYSPLIT atmospheric transport and dispersion modeling system, B. Am. Meteorol. Soc., 96, 20592077, 2015.

Sugimoto, N., Shimizu, A., Nishizawa, T., and Jin, Y.: Long-range transport of mineral dust observed with the Asian Dust and aerosol lidar observation Network (AD-Net), in: E3S Web of Conferences, Vol. 99, EDP Sciences, 2019.

Sun, J. and Liu, T.: The age of the Taklimakan Desert, Science, 312, 1621-1621, 2006.

Tanaka, T. Y. and Chiba, M.: A numerical study of the contributions of dust source regions to the global dust budget, Global Planet. Change, 52, 88-104, 2006.

Tanaka, T. Y., Kurosaki, Y., Chiba, M., Matsumura, T., Nagai, T., Yamazaki, A., Uchiyama, A., Tsunematsu, N., and Kai, K.: Possible transcontinental dust transport from North Africa and the Middle East to East Asia, Atmos. Environ., 39, 3901-3909, 2005.

Tesche, M., Ansmann, A., Mueller, D., Althausen, D., Mattis, I. N. A., Heese, B., Freudenthaler, V., Wiegner, M., Esselborn, M., Pisani, G., and Knippertz, P.: Vertical profiling of Saharan dust 
with Raman lidars and airborne HSRL in southern Morocco during SAMUM, Tellus B: Chem. Phys. Meteorol., 61, 144-164, 2009.

Textor, C., Schulz, M., Guibert, S., Kinne, S., Balkanski, Y., Bauer, S., Berntsen, T., Berglen, T., Boucher, O., Chin, M., Dentener, F., Diehl, T., Easter, R., Feichter, H., Fillmore, D., Ghan, S., Ginoux, P., Gong, S., Grini, A., Hendricks, J., Horowitz, L., Huang, P., Isaksen, I., Iversen, I., Kloster, S., Koch, D., Kirkevåg, A., Kristjansson, J. E., Krol, M., Lauer, A., Lamarque, J. F., Liu, X., Montanaro, V., Myhre, G., Penner, J., Pitari, G., Reddy, S., Seland, Ø., Stier, P., Takemura, T., and Tie, X.: Analysis and quantification of the diversities of aerosol life cycles within AeroCom, Atmos. Chem. Phys., 6, 1777-1813, https://doi.org/10.5194/acp-6-17772006, 2006.

Thompson, A. J., Skinner, C. B., Poulsen, C. J., and Zhu, J.: Modulation of mid-Holocene African rainfall by dust aerosol direct and indirect effects, Geophys. Res. Lett., 46, 3917-3926, 2019.

Uno, I., Eguchi, K., Yumimoto, K., Takemura, T., Shimizu, A., Uematsu, M., Liu, Z., Wang, Z., Hara, Y., and Sugimoto, N.: Asian dust transported one full circuit around the globe, Nat. Geosci., 2, 557-560, 2009.

VanCuren, R. A. and Cahill, T. A.: Asian aerosols in North America: Frequency and concentration of fine dust, J. Geophys. Res.Atmos., 107, AAC-19, 2002.

Veselovskii, I., Whiteman, D. N., Korenskiy, M., Suvorina, A., and Pérez-Ramírez, D.: Use of rotational Raman measurements in multiwavelength aerosol lidar for evaluation of particle backscattering and extinction, Atmos. Meas. Tech., 8, 41114122, https://doi.org/10.5194/amt-8-4111-2015, 2015.

Veselovskii, I., Goloub, P., Podvin, T., Bovchaliuk, V., Derimian, Y., Augustin, P., Fourmentin, M., Tanre, D., Korenskiy, M., Whiteman, D. N., Diallo, A., Ndiaye, T., Kolgotin, A., and Dubovik, O.: Retrieval of optical and physical properties of African dust from multiwavelength Raman lidar measurements during the SHADOW campaign in Senegal, Atmos. Chem. Phys., 16, 70137028, https://doi.org/10.5194/acp-16-7013-2016, 2016.
Veselovskii, I., Hu, Q., Goloub, P., Podvin, T., Korenskiy, M., Derimian, Y., Legrand, M., and Castellanos, P.: Variability in lidarderived particle properties over West Africa due to changes in absorption: towards an understanding, Atmos. Chem. Phys., 20, 6563-6581, https://doi.org/10.5194/acp-20-6563-2020, 2020.

Wang, Y., Sartelet, K. N., Bocquet, M., and Chazette, P.: Assimilation of ground versus lidar observations for $\mathrm{PM}_{10}$ forecasting, Atmos. Chem. Phys., 13, 269-283, https://doi.org/10.5194/acp13-269-2013, 2013.

Yu, Y., Kalashnikova, O. V., Garay, M. J., and Notaro, M.: Climatology of Asian dust activation and transport potential based on MISR satellite observations and trajectory analysis, Atmos. Chem. Phys., 19, 363-378, https://doi.org/10.5194/acp-19-3632019, 2019.

Yumimoto, K., Uno, I., Sugimoto, N., Shimizu, A., Liu, Z., and Winker, D. M.: Adjoint inversion modeling of Asian dust emission using lidar observations, Atmos. Chem. Phys., 8, 28692884, https://doi.org/10.5194/acp-8-2869-2008, 2008.

Yumimoto, K., Eguchi, K., Uno, I., Takemura, T., Liu, Z., Shimizu, A., and Sugimoto, N.: An elevated large-scale dust veil from the Taklimakan Desert: Intercontinental transport and three-dimensional structure as captured by CALIPSO and regional and global models, Atmos. Chem. Phys., 9, 8545-8558, https://doi.org/10.5194/acp-9-8545-2009, 2009.

Zhang, J., Campbell, J. R., Reid, J. S., Westphal, D. L., Baker, N. L., Campbell, W. F., and Hyer, E. J.: Evaluating the impact of assimilating CALIOP-derived aerosol extinction profiles on a global mass transport model, Geophys. Res. Lett., 38, L14801, https://doi.org/10.1029/2011GL047737, 2011.

Zhang, J., Hu, M.-M., Wang, Y.-Y., and Shu, H.-B.: TRIM32 protein modulates type I interferon induction and cellular antiviral response by targeting MITA/STING protein for K63-linked ubiquitination, J. Biol. Chem., 287, 28646-28655, 2012. 